\title{
Mechanisms of copper homeostasis in bacteria
}

\author{
José M. Argüello ${ }^{1 *}$, Daniel Raimunda ${ }^{2}$ and Teresita Padilla-Benavides ${ }^{1}$ \\ 1 Department of Chemistry and Biochemistry, Worcester Polytechnic Institute, Worcester, MA, USA \\ ${ }^{2}$ Instituto de Investigación Médica M. y M. Ferreyra, INIMEC-CONICET, Universidad Nacional de Córdoba, Córdoba, Argentina
}

\section{Edited by:}

Mathieu F. Cellier, Institut National de la Recherche Scientifique,

Canada

Reviewed by:

Fernando C. Soncini, CONICET, Argentina

James Imlay, University of Illinois at Urbana-Champaign, USA

Gregor Grass, Bundeswehr Institute of Microbiology, Germany

${ }^{*}$ Correspondence:

José M. Argüello, Department of

Chemistry and Biochemistry,

Worcester Polytechnic Institute, 100

Institute Road, Worcester,

MA 01609-2280, USA

e-mail: arguello@wpi.edu
Copper is an important micronutrient required as a redox co-factor in the catalytic centers of enzymes. However, free copper is a potential hazard because of its high chemical reactivity. Consequently, organisms exert a tight control on $\mathrm{Cu}^{+}$transport (entry-exit) and traffic through different compartments, ensuring the homeostasis required for cuproprotein synthesis and prevention of toxic effects. Recent studies based on biochemical, bioinformatics, and metalloproteomics approaches, reveal a highly regulated system of transcriptional regulators, soluble chaperones, membrane transporters, and target cuproproteins distributed in the various bacterial compartments. As a result, new questions have emerged regarding the diversity and apparent redundancies of these components, their irregular presence in different organisms, functional interactions, and resulting system architectures.

\section{Keywords: copper, homeostasis, transmembrane transport, metalloenzymes, metallochaperones, $\mathrm{Cu}^{+}-\mathrm{ATPases}$}

\section{INTRODUCTION}

Copper $(\mathrm{Cu})$ is a micronutrient required as a co-factor in multiple proteins. It participates in redox reactions (electron transport, oxidative respiration, denitrification, etc.) (Silva and Williams, 2001; Cobine et al., 2006; Tavares et al., 2006), and in some cases is also a structural element (Adman, 1991; Kaim and Rall, 1996). $\mathrm{Cu}$ homeostatic mechanisms were initially uncovered by phenotypic analysis of bacterial strains carrying mutations in genes participating in Cu tolerance (Odermatt et al., 1993; Outten et al., 2000; Rensing et al., 2000). Perhaps because of the simplicity of experiments measuring $\mathrm{Cu}$ tolerance and intracellular $\mathrm{Cu}$ accumulation, these mechanisms were the focus of much of the early research in the field. However, cell physiological fitness requires $\mathrm{Cu}$ homeostasis mechanisms that primarily address how this metal is distributed and targeted to cuproenzymes. Cells strive to supply $\mathrm{Cu}$ to these proteins via compartmentalization involving both, transport across membranes and trafficking within a given compartment (Robinson and Winge, 2010; Argüello et al., 2012). In addition, $\mathrm{Cu}$ homeostasis requires chelation by high affinity binding molecules and $\mathrm{Cu}^{+}$sensing by transcriptional regulators to maintain low levels of free $\mathrm{Cu}$, as the metal might participate in a number of deleterious reactions. These include the production of highly reactive radical oxygen species via the Fenton reaction and the interference with [Fe-S] cluster protein assembly (Gaetke and Chow, 2003; Macomber and Imlay, 2009; Dupont et al., 2011). In this review, we focus on these homeostatic mechanisms: sensors, transporters, chaperones, and chelators that distribute the ion to cuproproteins while maintaining beneficial $\mathrm{Cu}$ levels (Figure 1).

\section{BACTERIAL CUPROENZYMES}

The evolutionary driving force for copper usage in living organisms is mainly represented by the increase of diooxygen on Earth approximately 2 billion years ago (Boal and Rosenzweig, 2009). In parallel, $\mathrm{Fe}$ use increased as $\mathrm{Fe}^{2+} / \mathrm{Fe}^{3+}$ equilibrium shifted toward the more oxidized species, leaving the insoluble $\mathrm{Fe}^{3+}$ out of the scene. Instead, $\mathrm{Cu}$ emerged as a readily available biological redox factor because of the higher solubility of $\mathrm{Cu}^{2+}$. Additional determinants for $\mathrm{Cu}$ selection over other transition metals are found in its high polarizability and preferential geometries of coordination. Linear and trigonal coordination with $\mathrm{S} / \mathrm{N}$-ligands (soft bases), and to a lesser extent with O-ligands (hard base), result in high stability constants of $\mathrm{Cu}$ adducts suitable for traffic and transport. On the other hand, static/catalytic $\mathrm{Cu}$ sites present higher coordination numbers and more complex geometries with similar stability constants (Boal and Rosenzweig, 2009; Argüello et al., 2012). Most cuproenzymes described in this section harbor one or more $\mathrm{Cu}$ sites with tetrahedral or higher geometries. A thorough examination of coordination geometries is beyond the scope of this review.

Only a small repertoire of bacterial cuproenzymes is known (Table 1) (Garcia-Horsman et al., 1994; Claus, 2003; Nakamura and Go, 2005; Claus and Decker, 2006; Ridge et al., 2008; Boal and Rosenzweig, 2009; Rensing and McDevitt, 2013). However, as suggested by bioinformatics studies and in some cases shown by metalloproteomics approaches, bacteria are likely to have many yet unidentified cuproproteins (Ridge et al., 2008; Cvetkovic et al., 2010; Osman et al., 2010; Gladyshev and Zhang, 2013). Early analysis assumed that since most cuproproteins were localized in the bacterial periplasm or plasma membrane (Table 1), there was little need for cytoplasmic cuproproteins metallation. However, consideration of secretion systems might lead to alternative hypothesis. For instance, secretion of cuproenzymes via the Tat system implies that these likely acquire their metal in the cytoplasm. On the other hand, membrane cuproenzymes, as well as soluble enzymes secreted by the Sec system, fold and acquire $\mathrm{Cu}^{+}$from the periplasmic compartment. It can be proposed that this is not a random process. Since considerable energy 


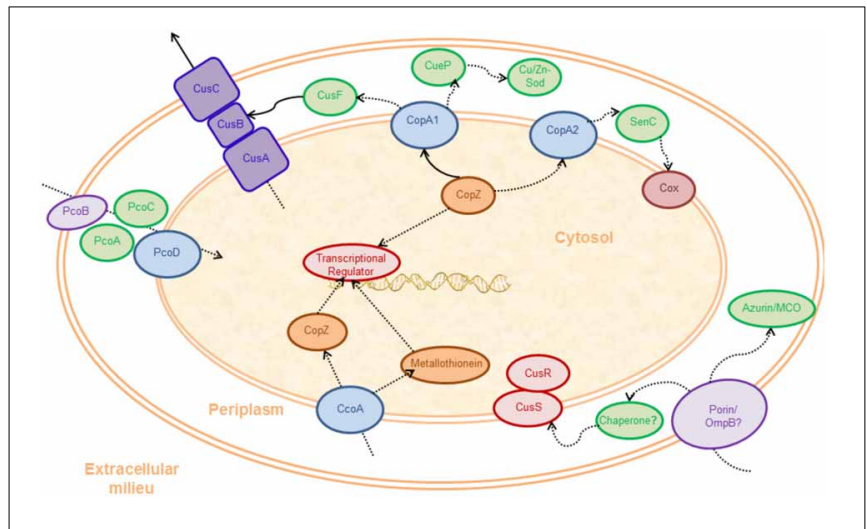

FIGURE 1 | Scheme of systems participating in $\mathrm{Cu}^{+}$homeostasis in a Gram-negative bacterial cell. The drawing represents the major systems, and not all cuproenzymes are depicted. Various bacteria contain different subsets of these molecules (Hernández-Montes et al., 2012).

Experimentally verified $\mathrm{Cu}^{+}$transfer and transport events are indicated with solid lines. Postulated $\mathrm{Cu}^{+}$fluxes are indicated with dotted lines. The colored shapes represent groups of proteins (various transcriptional regulators, various chaperones, etc.): putative outer membrane transporters (lavender), periplasmic $\mathrm{Cu}^{+}$chaperones and cuproenzymes (green), membrane cuproenzymes (magenta), Cus system (royal blue), inner membrane transporters (purple), transcriptional regulators (red), cytosolic $\mathrm{Cu}^{+}$chaperones (orange).

is spent during protein synthesis, the possibility of wrong metallation must be prevented. That is, highly regulated $\mathrm{Cu}$ transport and delivery systems should have co-evolved with the extracytoplasmic cuproenzymes. The participation of cytoplasmic influx and efflux systems in the eventual periplasmic metallation of $c b b_{3}$ cytochrome $c$ oxidase ( $c b b 3-\mathrm{COX})$ provides an example of the necessary passage of $\mathrm{Cu}^{+}$through a controlled delivery system (Figure 1) (González-Guerrero et al., 2010; Ekici et al., 2012b; Lohmeyer et al., 2012).

Heme-Cu respiratory oxidases constitute a large superfamily of cuproenzymes present in most bacteria (Garcia-Horsman et al., 1994; Richter and Ludwig, 2003). They are responsible for the reduction of $\mathrm{O}_{2}$ and the generation of the $\mathrm{H}^{+}$electrochemical gradient. The $\mathrm{O}_{2}$ reduction takes place in the binuclear center of subunit I (also referred as subunit N). This reduction center is composed of a heme iron juxtaposed to a $\mathrm{Cu}$ site $\left(\mathrm{Cu}_{B}\right)$. In addition, some $b a_{3}, c a a_{3}$ and $a a_{3}$ oxidases, contain a $\mathrm{Cu}_{\mathrm{A}}$ center in subunit II (Garcia-Horsman et al., 1994). Terminal oxidases acquire their $\mathrm{Cu}$ cofactors from periplasmic $\mathrm{Cu}^{+}$-chaperones. Homologs of the $\mathrm{Cu}^{+}$-chaperones ScoI/SenC have been proposed to perform this function in Pseudomonas putida, Rubrivibax gelatinosus, and Rhodobacter capsulatus as the corresponding deletion mutants lack cbb3COX activity (Banci et al., 2011; Ekici et al., 2012a; Lohmeyer et al., 2012). Studies in Pseudomonas aeruginosa revealed the requirement of cytosolic $\mathrm{Cu}^{+}$efflux through CopA2-like ATPases for $\mathrm{Cu}^{+}$insertion into cbb3-COX (González-Guerrero et al., 2010). Thus, it is likely that ScoI/SenC chaperones receive the metal from the ATPase. The identification of $R$. capsulatus CcoA has further supported the idea that cytoplasmic $\mathrm{Cu}^{+}$is channeled to the periplasm for COX metallation (Ekici et al.,
Table 1 | Bacterial Cuproenzymes*.

\begin{tabular}{lll}
\hline Enzyme & $\begin{array}{l}\mathrm{Cu}^{+} \quad \text { Cellular } \\
\text { binding localization } \\
\text { sites }\end{array}$ & $\begin{array}{l}\text { Secretion Function } \\
\text { mechanism }\end{array}$ \\
\hline
\end{tabular}

Cytochrome

oxidases

\begin{tabular}{|c|c|c|c|}
\hline $\begin{array}{l}c b b 3 \\
a a_{3}, c a a_{3}\end{array}$ & 1 & Inner membrane & $\begin{array}{l}\text { Dioxygen } \\
\text { reduction }\end{array}$ \\
\hline Nitrite reductase & 2 & $\begin{array}{l}\text { Inner membrane/ Tat } \\
\text { periplasmic }\end{array}$ & $\begin{array}{l}\mathrm{NO}^{2-} \\
\text { reduction }\end{array}$ \\
\hline $\begin{array}{l}\text { Nitric oxide } \\
\text { reductase }\end{array}$ & & Inner membrane & NO re \\
\hline
\end{tabular}

\begin{tabular}{|c|c|c|c|c|}
\hline $\begin{array}{l}\text { Nitrous oxide } \\
\text { reductase }\end{array}$ & 4 & $\begin{array}{l}\text { Inner membrane/ } \\
\text { periplasmic }\end{array}$ & $\mathrm{Tat}^{* *}$ & $\mathrm{~N}_{2} \mathrm{O}$ reduction \\
\hline $\begin{array}{l}\text { Cu,Zn-Superoxide } \\
\text { dismutases }\end{array}$ & & $\begin{array}{l}\text { Secreted/ } \\
\text { periplasmic/ } \\
\text { cytoplasmic }\end{array}$ & $\operatorname{Sec}^{* * *}$ & $\begin{array}{l}\text { Dismutation of } \\
\mathrm{O}_{2}^{-}\end{array}$ \\
\hline Plastocyanin & 1 & Thylakoid & $\operatorname{Sec}^{* * *}$ & $\begin{array}{l}\text { Electron } \\
\text { transfer }\end{array}$ \\
\hline Azurin & 1 & Periplasmic & $\operatorname{Sec}^{* *}$ & $\begin{array}{l}\text { Electron } \\
\text { transfer }\end{array}$ \\
\hline Laccases & 4 & Periplasmic & $\mathrm{Tat}^{* *}$ & $\begin{array}{l}\text { Phenols and } \\
\text { diamines } \\
\text { oxidation }\end{array}$ \\
\hline CueO & $2-4$ & Periplasmic & $\mathrm{Tat}^{* * *}$ & $\begin{array}{l}\text { Substrate } \\
\text { oxidation }\end{array}$ \\
\hline $\begin{array}{l}\text { NADH } \\
\text { dehydrogenase-2 }\end{array}$ & 1 & Inner membrane & & $\begin{array}{l}\text { NADH } \\
\text { oxidation }\end{array}$ \\
\hline Tyrosinases & 1 & Secreted & $\mathrm{Tat}^{* * *}$ & $\begin{array}{l}\text { Monophenol } \\
\text { hydroxylation }\end{array}$ \\
\hline $\begin{array}{l}\text { Particulate } \\
\text { methane } \\
\text { monoxygenases }\end{array}$ & 2 & Membrane & & $\begin{array}{l}\text { Methane } \\
\text { oxidation }\end{array}$ \\
\hline Amine oxidases & 1 & $\begin{array}{l}\text { Periplasmic/ } \\
\text { secreted }\end{array}$ & $\mathrm{Tat}^{* *}$ & $\begin{array}{l}\text { Oxidative } \\
\text { deamination }\end{array}$ \\
\hline $\begin{array}{l}\text { Polysaccharide } \\
\text { oxygenases }\end{array}$ & 1 & Secreted & $\mathrm{Tat}^{* * *}$ & $\begin{array}{l}\text { Cellulose } \\
\text { oxidation }\end{array}$ \\
\hline
\end{tabular}

${ }^{*}$ References are in the text. ${ }^{* *}$ Based on the presence of signal sequences. ${ }^{* * *}$ Based on experimental evidence.

2012b). CcoA is a member of the major facilitator superfamily (MFS) of transport proteins. It has been proposed that it imports $\mathrm{Cu}$ into the cytoplasm and is required for $c b b_{3}$ assembly. Regarding oxidases containing a $\mathrm{Cu}_{\mathrm{A}}$ site, characterization of the Bradyrhizobium japonicum $a_{3}$ oxidase suggests that the metal binding PcuC acts as the periplasmic $\mathrm{Cu}^{+}$-chaperone (Serventi et al., 2012). The source of $\mathrm{Cu}$ for PcuC loading has not been identified. 
Three enzymes involved in the bacterial denitrification pathway (i.e., the nitrite reduction to dinitrogen) are periplasmic cuproenzymes: nitrite reductase (Nir), nitric oxide reductase (qCuNOR), and nitrous oxide reductase $\left(\mathrm{N}_{2} \mathrm{OR}\right.$ ) (Messerschmidt et al., 1993; Brown et al., 2000; Zumft, 2005). Nir and $\mathrm{N}_{2} \mathrm{OR}$ are attached to the inner membrane. Nir is homotrimeric with each subunit containing type 1 and $2 \mathrm{Cu}$ centers. $\mathrm{N}_{2} \mathrm{OR}$ is homodimeric with a binuclear $\mathrm{Cu}_{\mathrm{A}}$ site related to electron transfer and a multinuclear $\mathrm{Cu}_{\mathrm{z}}$ related to catalysis (Brown et al., 2000). It is assumed that these three enzymes are exported via the Tat secretion system (Saunders et al., 2000; Berks et al., 2003). However, Nir is apparently secreted via Tat in some organisms and via Sec in others (Berks et al., 2000b). In any case, it has been proposed that Nir proteins present one $\mathrm{Cu}^{+}$binding site at the subunits interface with metal ligands located in two separate polypeptides. $\mathrm{Cu}$ would bind these sites during or after oligomer formation in the periplasm (Godden et al., 1991; Berks et al., 2003). Similarly, it has been reported that assembly of the $\mathrm{Cu}_{\mathrm{A}}$ and $\mathrm{Cu}_{\mathrm{Z}}$ center of the Pseudomonas stutzeri $\mathrm{N}_{2} \mathrm{OR}$ occurs in the periplasm and nos genes are required for metallation (Wunsch et al., 2003).

Members of the superoxide dismutase (Sod) harbor different active redox metallic co-factors in their catalytic centers. Two major groups have been described in bacteria, SodA containing usually $\mathrm{Mn}^{2+}$ (and in some cases $\mathrm{Fe}^{2+}$ ), and SodC carrying $\mathrm{Cu}^{+}$and $\mathrm{Zn}^{2+}$. Most bacterial $\mathrm{Cu}, \mathrm{Zn}$-SodC are periplasmic proteins. These are secreted unfolded by the Sec secretion system and likely acquire the metals in the periplasm (Kroll et al., 1995; Imlay and Imlay, 1996). Recent studies of Salmonella enterica sv. Typhimirium $\mathrm{Cu}, \mathrm{Zn}$-Sod have identified some of the proteins involved in periplasmic metallation. Salmonella virulent strains contain SodCI and SodCII (Fang et al., 1999; Krishnakumar et al., 2007; Rushing and Slauch, 2011). These are both periplasmic proteins. SodCI appears required for virulence. Salmonella mutant strains lacking functional $\mathrm{Cu}^{+}$-ATPases, CopA, and GolT, have inactive SodCII (Osman et al., 2013). Mutation of the periplasmic $\mathrm{Cu}^{+}$-chaperone CueP also results in inactive SodCII forms. Consequently, it was hypothesized that $\mathrm{Cu}^{+}$might be transferred from either CopA or GolT to CueP to be inserted in SodCII. Further studies are necessary to understand the apparent redundancy of both ATPases, as well as the $\mathrm{Cu}$ transfer mechanism among the involved proteins. Conversely, in Mycobacterium tuberculosis and Mycobacerium smegmatis, the $\mathrm{Cu}, \mathrm{Zn}$-Sod is located in the cytosol whereas the Fe/Mn-SodA is secreted via the SecA2 pathway and is metallated outside the cell (Braunstein et al., 2003; Padilla-Benavides et al., 2013a). Therefore, these organisms require a cytoplasmic $\mathrm{Cu}$-loading mechanism to produce functional $\mathrm{Cu}, \mathrm{Zn}$-Sod.

The superfamily of cupredoxins is characterized by an antiparallel $\beta$-barrel structure that presents a type $1 \mathrm{Cu}$ binding site. This group includes plastocyanin located in the thylakoid, and a variety of periplasmic proteins such as azurin, multicopper oxidases (MCO), laccases, and nitrosocyanin (Redinbo et al., 1994; Donaire et al., 2002; Berks et al., 2003; Zaballa et al., 2012). In cyanobacteria, plastocyanin participates in the electron shuttling to photosystem I (Redinbo et al., 1994) and also confers protection against $\mathrm{Cu}^{+}$stress (Tottey et al., 2012). Mutant strains lacking $\mathrm{Cu}^{+}$-ATPases PacS or CtaA have impaired photosynthetic electron transport via plastocyanin and cytochrome oxidase activity, suggesting that these transporters are required for the metallation of these proteins (Tottey et al., 2001). Periplasmic azurins participate in electron shuttling for deamination and denitrification processes by donating electrons to nitrite reductases (De Rienzo et al., 2000). P. aeruginosa azurin participates in the cellular response to $\mathrm{Cu}$ stress. For instance, mutation of $P$. aeruginosa $\operatorname{cin} A$, an azurin/plastocyanin-like protein, leads to increased sensitivity to $\mathrm{Cu}^{2+}$ in the media (Elguindi et al., 2009). Deletion of either $P$. aeruginosa $\mathrm{Cu}^{+}$-ATPase, CopA1, or CopA2, induces an increase in azurin transcription as a cellular response to $\mathrm{Cu}^{+}$-derived oxidative stress (Raimunda et al., 2013). However, whether azurins are metallated by the transporters or participate in $\mathrm{Cu}^{+}$oxidation has not been established.

Ascorbate oxidases, laccases, and ceruloplasmin are homologous small blue MCO (Messerschmidt et al., 1993; Nakamura et al., 2003). Laccases, for instance, are involved in the oxidation of phenolic compounds (Claus, 2003). Laccases and ascorbate oxidases present a mononuclear type $1 \mathrm{Cu}$ site -homologous to other cupredoxins- and a trinuclear $\mathrm{Cu}$ center. Ceruloplasmin has three mononuclear $\mathrm{Cu}$ sites and a trinuclear $\mathrm{Cu}$ domain (Nakamura et al., 2003). CueO and PcoA are MCO up-regulated by high $\mathrm{Cu}^{+}$ concentrations through the $c u e R$ regulon (Outten et al., 2000). It has been observed that Escherichia coli $\mathrm{CueO}$ is folded in the cytoplasm and exported via the Tat system (Outten et al., 2000; Grass and Rensing, 2001). Based on differences in $\mathrm{Cu}^{+}$amounts relative to the binding capacity of $\mathrm{CueO}$, it was proposed that they contribute to periplasmic metal tolerance by oxidizing the ion to the less toxic form $\mathrm{Cu}^{2+}$ (Roberts et al., 2002; Singh et al., 2004). However, S. enterica sv. Typhimurium CueO seems to also play a significant role in $\mathrm{Cu}^{+}$homeostasis under anaerobiosis (Espariz et al., 2007).

NADH dehydrogenase-2 (NDH-2), part of the electron transport chain, is a membrane bound protein that catalyzes the electron transfer from NADH to quinone (Jaworowski et al., 1981; Bjorklof et al., 2000). NDH-2 $\mathrm{Cu}^{2+}$-reductase activity was described in E. coli (Rodríguez-Montelongo et al., 1995; Rapisarda et al., 1999). Although not essential for Cu metabolism, $\mathrm{NDH}-2$ is likely important for cell growth under $\mathrm{Cu}$ stress (Rodríguez-Montelongo et al., 2006). Moreover, E. coli NDH2 presents four domains. Domain IV likely anchors the protein to the membrane. Domain III faces the cytosolic side near the FAD-binding site, shares homology with the cytosolic metal binding domains $(\mathrm{MBD})$ of $\mathrm{Cu}^{+}$-ATPases and might be relevant for cytoplasmic $\mathrm{Cu}^{+}$sensing (Rapisarda et al., 2002). The biological role for the $\mathrm{Cu}^{+}$-reducing enzymatic activity, as well as the characterization of the secretion mechanism and metallation of this enzyme, requires further investigation.

In eukaryotic cells, tyrosinase is required for synthesizing melanin. Some bacteria from the genus Streptomyces produce a melanin-like pigment (Katz et al., 1983; Hintermann et al., 1985; Huber et al., 1985; Ikeda et al., 1996). Tyrosinases catalyze the orthohydroxylation of monophenol and the subsequent oxidation of the diphenolic product to the resulting quinone. The quinone product is a reactive precursor for the synthesis of melanin pigments. Tyrosinases contain a flexible dinuclear $\mathrm{Cu}$ center required for catalysis (Matoba et al., 2006). Bacterial 
tyrosinase is encoded in a bicistronic operon composed by genes coding for a "caddie" chaperone protein (melC1) and tyrosinase (melC2) (Katz et al., 1983; Ikeda et al., 1996). Tyrosinases are secreted via the Tat pathway (Berks et al., 2003). MelC1 appears to function as $\mathrm{Cu}^{+}$-chaperone, forming a transient complex with the apo-MelC2. This would facilitate the incorporation of $\mathrm{Cu}^{+}$ and the subsequent secretion of functional tyrosinase (Chen et al., 1992, 1993; Matoba et al., 2006).

Methane monooxygenases (MMO) are $\mathrm{Cu}^{+}$-containing enzymes present in methanotropic bacteria. There are two MMO forms, membrane-bound (pMMO) and cytosolic (sMMO). Most organisms present the pMMO form; however, in some bacteria both types are present. Interestingly, the expression of both proteins is regulated by the availability of $\mathrm{Cu}$ (Nielsen et al., 1997). The Methylococcus capsulatus (Bath) pMMO comprises three subunits, encoded by the $p m o B, p m o A$, and $p m o C$ genes (Semrau et al., 1995; Stolyar et al., 1999). Copper stoichiometries ranging from 2 to 15 ions per opy complex have been reported (Nguyen et al., 1998; Basu et al., 2003). Ions appear organized in multiple trinuclear clusters composed of one $\mathrm{Cu}^{2+}$ and two $\mathrm{Cu}^{+}$ ions (Nguyen et al., 1996, 1998). These sites are hypothesized to function for catalysis and electron transfer. Interestingly, the uptake of methanobactin-bound $\mathrm{Cu}$ via TonB dependent transport appears critical for pMMO metallation (Balasubramanian and Rosenzweig, 2008).

$\mathrm{Cu}^{+}$-dependent amine oxidases $(\mathrm{CuAO})$ are rare in bacteria but they provide the ability to obtain carbon and nitrogen from primary amines by oxidative deamination (Wilmot et al., 1997). The enzyme is induced in conditions where biogenic primary amine substrate is the sole source of carbon (Gladyshev and Zhang, 2013). Bacterial $\mathrm{Cu}^{+}$-dependent polysaccharide oxygenases (AA10) are secreted proteins involved in breaking internal linkages in plant cellulose (Levasseur et al., 2013). AA10 binds one $\mathrm{Cu}^{+}$atom with high affinity. The metal ion is coordinated in a $\mathrm{T}$-shaped configuration by three $\mathrm{N}$ atoms from two His side chains and the amino terminus (Hemsworth et al., 2013). Although these enzymes are secreted via the Tat pathway (Berks et al., 2003), there is no information regarding their metallation mechanisms.

This assessment of various cuproenzymes makes clear that they fulfill various roles essential for bacterial survival. It is also apparent that well-regulated mechanisms should be responsible for delivering the metal to final targets. Relevant questions immediately emerge when considering $\mathrm{Cu}$ delivery models. Are chaperones promiscuous in their interactions with various targets? If they are specific, how is the allocation of $\mathrm{Cu}$ to the various targets regulated? Moreover, the existence of novel uncharacterized cuproproteins must be also considered. Recent efforts using metalloproteomic approaches support this idea. For instance, liquid chromatography, high-throughput tandem mass spectrometry (HT-MS/MS) and inductively coupled plasma mass spectrometry (ICP-MS) were combined to identify cytoplasmic metalloproteins in the extremophile Pyrococcus furiosus (Cvetkovic et al., 2010). Chromatography fractions revealed 343 metal peaks. Among these, 158 did not correspond to any predicted metalloprotein, supporting the likelihood of numerous novel cuproproteins.

\section{MAINTAINING THE $\mathrm{Cu}^{+}$QUOTA: $\mathrm{Cu}^{+}$-SENSING AND TRANSCRIPTIONAL REGULATION OF HOMEOSTATIC SYSTEMS}

Cells control alkali ion levels regulating transmembrane transport through various mechanisms: (a) modulating transport turnover rates through chemical modification and allosteric ligand binding; (b) managing the incorporation and removal of transporter proteins at the required membrane (eukaryotes); and (c) transcriptional regulation of transporter abundance. The high affinity binding of transition metals to their transporters, as well as the inability of apo-chaperones to accept $\mathrm{Cu}^{+}$back from the exporting ATPase, makes the transmembrane transport functionally irreversible. Consequently, bacterial cells regulate this process mainly through transcriptional control by modifying the transporter abundance. This strategy facilitates the co-regulation of chaperone and chelating metallothioneins. Four families of $\mathrm{Cu}^{+}$-sensing homodimeric transcriptional regulators have been identified. MerR is a transcriptional activator, while CsoR, CopY, and ArsR are transcriptional repressors (Ma et al., 2009c).

CueR-like proteins, members of the MerR family, are present in most proteobacteria (Ma et al., 2009c). These activate the transcription of $\mathrm{Cu}^{+}$-ATPases (CopA) and $\mathrm{Cu}^{+}$chaperones (CopZ, CueP, etc.) in response to high concentrations of $\mathrm{Cu}^{+}$(Outten et al., 2000; Grass and Rensing, 2001; Pontel and Soncini, 2009). In the presence of low metal levels, the metalloregulator binds to DNA in a conformation that prevents the DNA-RNA polymerase interaction, therefore repressing transcription (Ma et al., 2009c; Reyes-Caballero et al., 2011). When cytosolic $\mathrm{Cu}^{+}$level increases, metal binding to the sensor induces changes in the DNA binding region. The long-range communication between metal and DNA binding sites appears mediated by a hydrogen bond network. Once the cytosolic $\mathrm{Cu}^{+}$levels return to normal, the metal-resistance genes are down regulated to basal levels. It is possible that the metal is released from the sensor-DNA complex followed by disassociation of the regulatory complex. However, this is an unlikely phenomenon considering the high $\mathrm{Cu}^{+}$binding affinity of CueR $\left(10^{-21} \mathrm{M}\right)$ (Changela et al., 2003). Rather, the exchange of apo- and holo-forms appears possible since both forms of MerR proteins interact with DNA with similar affinities (Brown et al., 2003; Joshi et al., 2012). Although CueR and other $\mathrm{Cu}^{+}$sensing regulators bind the metal with high affinity, metal selectivity appears to be conferred by the singular coordination geometry of binding sites and the capability to induce the required allosteric changes to influence DNA conformations (Ma et al., 2009c; Reyes-Caballero et al., 2011). CueR-like sensors bind $\mathrm{Cu}^{+}$with two Cys in two symmetrical loops in the periphery of the dimer. Nevertheless, the detail structure of the loop and the influence of the second coordination sphere are critical as shown by selectivity changes associated with minimal modifications in the region (Checa et al., 2007).

CsoR was identified as the $\mathrm{Cu}^{+}$sensor in M. tuberculosis (Liu et al., 2007). This $\mathrm{Cu}^{+}$-responsive repressor controls the expression of the $c s o$ operon ( $c s o R, R v 0968$, the $\mathrm{Cu}^{+}$-ATPase $c t p V$, and $R v 0970$ ). Members of this family are widely distributed in most bacterial species (Smaldone and Helmann, 2007; Ma et al., 2009a; Sakamoto et al., 2010; Corbett et al., 2011). In CsoR, $\mathrm{Cu}^{+}$is bound in a trigonal coordination by two Cys and one His (Liu 
et al., 2007; Ma et al., 2009b). These sites might also bind $\mathrm{Ni}^{2+}$, $\mathrm{Zn}^{2+}$, or $\mathrm{Co}^{2+}$, but these place the sensors in non-active conformations (Ma et al., 2009a). Thus, as in the case of CueR-like proteins, binding geometry appears critical for selectivity.

Members of the CopY family are present in Firmicutes. Enterococcus hirae CopY regulates the copYZBA operon, where $\operatorname{cop} Z$ encodes a $\mathrm{Cu}^{+}$-chaperone, $\operatorname{cop} A$ a CopA1-like ATPases (see below) and $\operatorname{cop} B$ is a $\mathrm{Cu}^{2+}$-ATPase (Argüello et al., 2007; Solioz et al., 2010). Both ATPases mediate the efflux of cytoplasmic $\mathrm{Cu}^{+/ 2+}$ (Raimunda et al., 2011). A conserved CXCXXXCXC motif appears to mediate the binding of two $\mathrm{Cu}^{+}$per CopY monomer. CopY is also interesting because its capability to exchange $\mathrm{Cu}^{+}$with the cytoplasmic $\mathrm{Cu}^{+}$-chaperone $\mathrm{CopZ}$ has been demonstrated (Cobine et al., 1999). This has not been shown for other $\mathrm{Cu}^{+}$sensors.

Oscillatoria brevis BxmR is the only identified $\mathrm{Cu}^{+}$sensor member of the ArsR family (Liu et al., 2004, 2008). This binds $\mathrm{Ag}^{+}$and $\mathrm{Cu}^{+}$through formation of a binuclear $\mathrm{Cu}_{2} \mathrm{~S}_{4}$ cluster similar to that of E. hirae CopY. Like other described sensors, it regulates the expression of a metallothionein and a $\mathrm{Cu}^{+}$-ATPase.

Less is known about the role of bacterial two-component systems in the regulation of $\mathrm{Cu}^{+}$homeostatic systems. The twocomponent system CusRS regulates the cusCFBA system under anaerobic conditions (Outten et al., 2001; Rensing and Grass, 2003; Yamamoto and Ishihama, 2005; Gudipaty et al., 2012). This is a three-component channel/pore that controls periplasmic $\mathrm{Cu}^{+}$(Outten et al., 2001; Rensing and Grass, 2003). The Cus complex is composed by a plasma membrane energy-providing channel, CusA; an outer membrane pore, CusC; CusB, a periplasmic protein linking CusA and CusC; and a soluble periplasmic $\mathrm{Cu}^{+}$-chaperone, CusF (Outten et al., 2001; Rensing and Grass, 2003). In the case of CusRS, the periplasmic sensor domain of the transmembrane histidine kinase CusS binds $\mathrm{Cu}^{+}$. This drives the subsequent activation of the cytoplasm regulator CusR. The pcoABCDE cluster also appears to be regulated by a twocomponent system, PcoRS (Rouch and Brown, 1997; Munson et al., 2000). The Pco proteins, whose function is not fully understood, appear to contribute to the control of periplasmic $\mathrm{Cu}^{+}$in E. coli and other Gram-negative bacteria (Brown et al., 1995; Rouch and Brown, 1997; Lee et al., 2002; Rensing and Grass, 2003; Djoko et al., 2008; Hernández-Montes et al., 2012). Sequence analysis and experimental evidence suggest that PcoA is a periplasmic MCO. PcoB may function as the outer membrane transporter, while PcoD appears to be the inner membrane transporter that drives $\mathrm{Cu}^{+}$entry from the periplasm to the cytoplasm. PcoC is a periplasmic $\mathrm{Cu}^{+}$-chaperone, and $\mathrm{PcoE}$ is an additional putative chaperone.

\section{$\mathrm{Cu}^{+}$TRANSPORT SYSTEMS \\ $\mathrm{Cu}^{+}$-TRANSPORTING P-TYPE ATPASES}

The prevailing $\mathrm{Cu}^{+}$transmembrane transporters throughout the

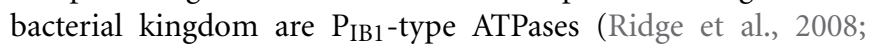
Hernández-Montes et al., 2012). These are polytopic membrane transporters that couple the unidirectional $\mathrm{Cu}^{+}$efflux to the hydrolysis of ATP. Initial functional characterization of $\mathrm{Cu}^{+}$ATPases showed that they are responsible for maintaining cytosolic $\mathrm{Cu}^{+}$levels (Rensing et al., 2000; Argüello et al., 2007; Osman and Cavet, 2008; Solioz et al., 2010). The mechanism coupling the ATP hydrolysis to $\mathrm{Cu}^{+}$translocation appears to follow the classical features of the Post-Albers catalytic cycle. This describes solute transport by well-characterized P-type ATPases (Palmgren and Nissen, 2011; Raimunda et al., 2011). Perhaps the most significant differences from alkali metal transport ATPases are those related to the substrate access to transport sites (Figure 2). That is, free $\mathrm{Cu}^{+}$is absent in the cytoplasm and reaches the transmembrane sites after delivery by $\mathrm{Cu}^{+}$-chaperones. This substrate transfer is mediated by ligand exchange following protein-protein interactions (González-Guerrero and Argüello, 2008; GonzálezGuerrero et al., 2009; Raimunda et al., 2011). The ATPase transmembrane metal binding sites (TM-MBS) bind two $\mathrm{Cu}^{+}$with extremely high affinities (González-Guerrero et al., 2008). This high affinity, together with inability of the apo-chaperone to remove $\mathrm{Cu}^{+}$from the TM-MBS prevents the backward release of $\mathrm{Cu}^{+}$into the cytoplasm. It is hypothesized that the enzyme releases $\mathrm{Cu}^{+}$to the extra-cytoplasmic compartments in a similar fashion; i.e., delivering the metal to an appropriate chaperone (Raimunda et al., 2011). Additional unanswered aspects of transport is whether another ion, like $\mathrm{H}^{+}$, is counter transported and

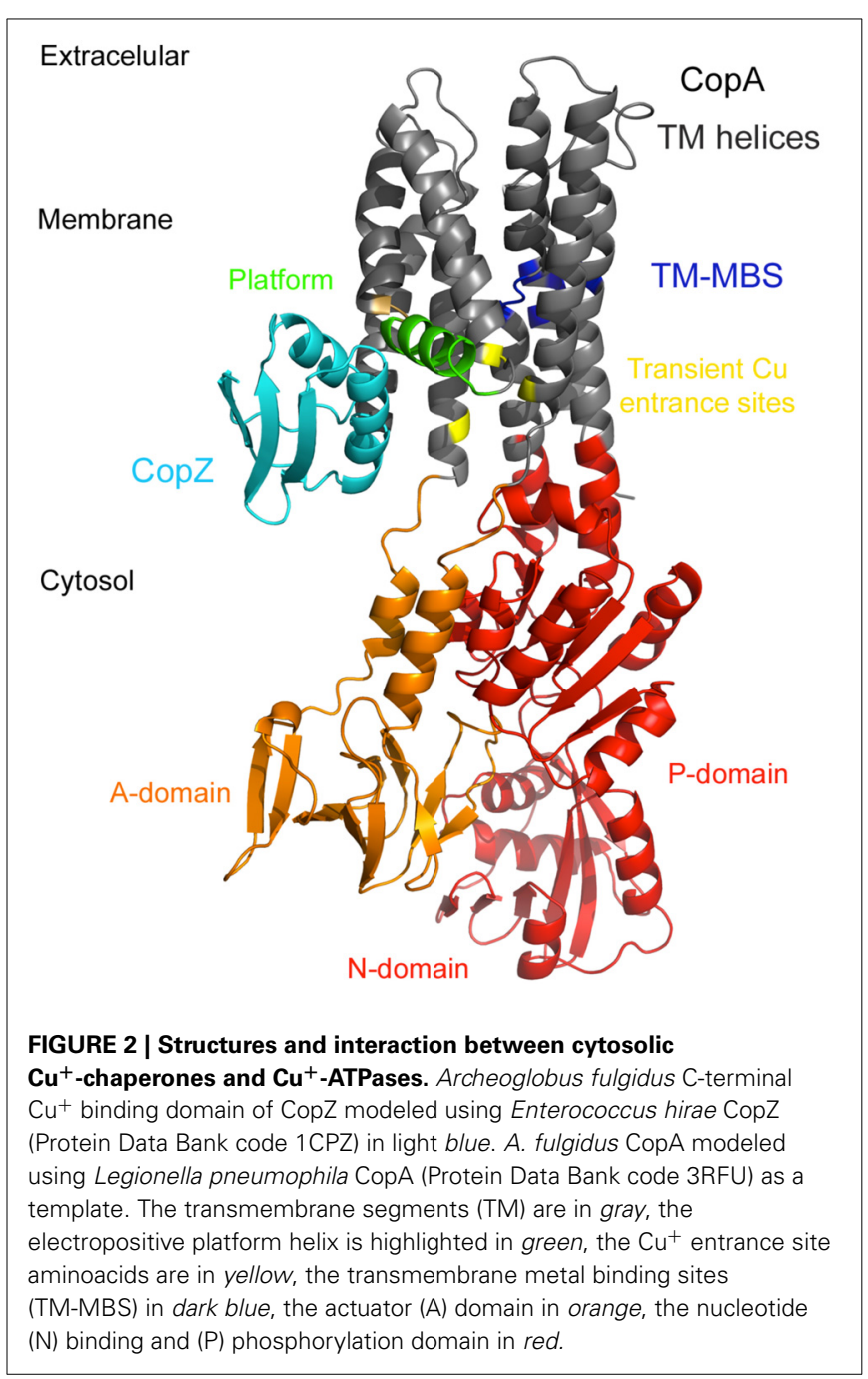


whether $\mathrm{Cu}^{+}$transport is electrogenic. However, considering the general low $\mathrm{Cu}^{+}$transport rate of $\mathrm{Cu}^{+}$-ATPases the exchanged mass of the counter ion might not be significant enough to alter any metabolic process.

The crystal structure of Legionella pneumophila CopA shows the arrangement of the distinct elements of $\mathrm{Cu}^{+}$-ATPases (Gourdon et al., 2011) (Figure 2). The cytoplasmic ATP-binding domain (ATP-BD) is comprised of the phosphorylation (P-), nucleotide binding $\left(\mathrm{N}_{-}\right)$, and actuator (A-) domains. Within the $\mathrm{P}$-domain is the conserved DKTGT sequence. Phosphorylation of the aspartyl residue during the enzyme catalytic cycle is the hallmark of the P-type ATPase family of transporters. Importantly, six invariant residues in the TM region constitute the TMMBS and are the determinants of $\mathrm{Cu}^{+}$specificity (Argüello, 2003; González-Guerrero et al., 2008). Besides bacterial $\mathrm{Cu}^{+}$ATPases contain one or two cytosolic N-terminal metal binding domains (N-MBD) (Argüello, 2003). N-MBDs are structurally similar to the Atx1-like family of $\mathrm{Cu}^{+}$-chaperones (Boal and Rosenzweig, 2009). These domains exchange $\mathrm{Cu}^{+}$with cytoplasmic chaperones with $\mathrm{K}_{\mathrm{eq}} \approx 1$ (Argüello et al., 2007; Boal and Rosenzweig, 2009; Banci et al., 2010a,b; Robinson and Winge, 2010). Therefore, they sense the levels of cytoplasmic $\mathrm{Cu}^{+}$and regulate the ATPase turnover rate through a $\mathrm{Cu}^{+}$-dependent interaction with the catalytic soluble domains (Mandal and Argüello, 2003; González-Guerrero et al., 2009). The structure of L. pneumophila CopA also showed a unique feature on the cytosolic side of the second TM helix: a Gly-Gly kink that exposes an electropositive platform to the cytoplasm, as well as three conserved residues that constitute the $\mathrm{Cu}^{+}$"entrance" site (Met, Glu, Asp) (Gourdon et al., 2011). The platform is where $\mathrm{Cu}^{+}$-loaded chaperones interact with the transporter while delivering the ion for transport (Padilla-Benavides et al., 2013b). These conserved "entrance" residues are required to take $\mathrm{Cu}^{+}$from the chaperone via ligand exchange. $\mathrm{Cu}^{+}$ions only transiently interacts with these residues during transfer to the TM-MBS, where they reside until ATP hydrolysis drives the necessary E1PE2 transition associated with ion translocation.

\section{Cus SYSTEM}

The Cus system, first identified in E. coli, is proposed to transport cytosolic $\mathrm{Cu}^{+}$across the cell membrane toward the extracellular milieu (Figure 1). This efflux system is comprised of a proton-substrate carrier (CusA) and an outer membrane pore (CusC), which are joined in the periplasm by a linker protein, CusB (Zgurskaya and Nikaido, 1999; Su et al., 2009; Kim et al., 2011). A forth component, $\mathrm{CusF}$ is a periplasmic $\mathrm{Cu}^{+}$-chaperone found in some organisms (Kim et al., 2011; Mealman et al., 2011; Hernández-Montes et al., 2012).

Comparative studies of CopA and Cus proteins expression have suggested that Cus is not the principal $\mathrm{Cu}^{+}$efflux system in cells growing under aerobiosis (Franke et al., 2001; Outten et al., 2001). This model considers that CopA's role is in fact supported by the periplasmic oxidase $\mathrm{CueO}$. Thus, under anaerobic conditions where $\mathrm{CueO}$ would be inactive, Cus would become relevant in $\mathrm{Cu}^{+}$detoxification (Outten et al., 2001). In agreement with this idea, bioinformatics analyses showed that the Cus system coexists with CopA in $44 \%$ of the organisms of the $\gamma$-proteobacteria group (Hernández-Montes et al., 2012). Among these, the pair CusA/CusC seems to be essential for the assembly of the efflux system, since CusB is absent in most members of this class. Then, CusB may be a dispensable accessory protein for the formation of the CusA-CusC channel, or homologous proteins from other RND complexes may fulfill its function (Hernández-Montes et al., 2012). The periplasmic chaperone CusF is the least conserved element of the Cus system (Hernández-Montes et al., 2012). CusF is a small $(10 \mathrm{kDa})$ protein which binds one $\mathrm{Cu}^{+}$atom in a tetragonal coordination with two Met, one His, and a conserved Trp. The Trp residue stabilizes the $\mathrm{Cu}^{+}$binding, thus regulating metal transference and preventing redox reactions (Xue et al., 2008). Yeast two-hybrid assays and NMR analysis have shown that CusF interacts with both CusB and CusC (Franke et al., 2003; Mealman et al., 2011). Consequently, a proposed transport mechanism is that CusF delivers periplasmic $\mathrm{Cu}^{+}$to CusABC for extracellular transport (Kim et al., 2011; Mealman et al., 2011). However, the transport of cytoplasmic $\mathrm{Cu}^{+}$through the CusA antiporter has also been postulated based upon the CusA structure (Fu et al., 2013). Transport experiments are clearly necessary to discriminate among these alternative hypothetical Cus transport mechanisms.

\section{Pco SYSTEM}

Pco systems were the first characterized genetic determinants of bacterial $\mathrm{Cu}$ resistance (Tetaz and Luke, 1983; Bender and Cooksey, 1986; Cha and Cooksey, 1991). An E. coli strain showing a 7-fold increase in $\mathrm{Cu}$ resistance was isolated from a piggery that fed its animals a high $\mathrm{Cu}$ diet to promote growth. The phenotype was associated with the plasmid pRJ1004. This enabled the E. coli transconjugants to thrive in media containing up to $20 \mathrm{mM}$ $\mathrm{Cu}^{2+}$ (Tetaz and Luke, 1983). Similarly, increased Cu resistance in Pseudomonas syringae pv. tomato strains was shown to be determined by the plasmid pPT23D (Cooksey, 1987, 1990). Both plasmids contain 6-7 clustered genes, pcoABCDRSE in E. coli and copABCDRS in P. syringae (Mellano and Cooksey, 1988b; Brown et al., 1995). PcoB/CopB and PcoD/CopD are membrane proteins located in the outer and inner membranes respectively (Figure 1), participating in $\mathrm{Cu}$ transport. PcoA/CopA and PcoC/CopC are soluble periplasmic $\mathrm{Cu}^{+}$-binding proteins (Cha and Cooksey, 1991, 1993; Lee et al., 2002). Initial characterization in $P$. syringae pv. tomato pointed that $\operatorname{cop} A$ and $\operatorname{cop} B$ are necessary to confer partial $\mathrm{Cu}^{+}$resistance, whereas $\operatorname{cop} C$ and $\operatorname{cop} D$ genes are required for full resistance (Mellano and Cooksey, 1988a). However, indirect evidence provided by phenotypic characterization of $\operatorname{cop} C$ and $\operatorname{cop} D$ mutant strains suggests that these genes are required for $\mathrm{Cu}$-uptake across the cell membrane. Cells expressing both proteins were hypersensitive toward $\mathrm{Cu}$, and the presence of any of these two genes leads to slight $\mathrm{Cu}$ accumulation (Cha and Cooksey, 1993). Direct metal transport determinations are necessary to establish the role of these proteins in $\mathrm{Cu}$ homeostasis. The PcoA sequence shows homology to MCO, binds $\mathrm{Cu}$, and has MCO activity (Djoko et al., 2008) and is predicted to be translocated into the periplasm via the Tat pathway (Berks et al., 2000a; Lee et al., 2002). The PcoC structure shows 2 solventexposed $\mathrm{Cu}$ binding sites and its participation in $\mathrm{Cu}$ handling and transferring in the periplasm has been suggested, although 
its interacting client proteins remain unknown (Arnesano et al., 2002b, 2003). PcoE is homologous to the Salmonella silver resistance gene silE (Cha and Cooksey, 1993; Gupta et al., 2001). It has been postulated that PcoE might provide initial sequestration of $\mathrm{Cu}$ in the periplasm before the remaining genes of the pco system are fully induced (Lee et al., 2002). Bacillus subtilis $y c n J$ encodes a protein with high homology to domains found in PcoC and PcoD (Chillappagari et al., 2009). The presence of the $\mathrm{Cu}^{+}$-chelator BCA in the media led to reduced cytoplasmic $\mathrm{Cu}$, induction of $y c n J$ expression, and impaired growth of an $y c n J$ deletion mutant strain, suggesting a role for $\mathrm{YcnJ}$ in $\mathrm{Cu}$ import. Importantly, amino acids involved in the $\mathrm{Cu}^{2+}$ binding of CopC are conserved in YcnJ sequence (Arnesano et al., 2003; Chillappagari et al., 2009).

Although counterintuitive when considering a $\mathrm{Cu}$ resistance mechanism, the biological function of Pco systems seems to be related to periplasmic, and probably, intracellular $\mathrm{Cu}$ storage pools (Figure 1) (Cooksey, 1993). The latter function is probably mediated by CopC/CopD pair. However, the pco system is not able to rescue the $\mathrm{Cu}$ sensitive phenotype in the $\operatorname{cop} A$ mutant of E. coli, suggesting that cooperation between CopC/CopD-dependent $\mathrm{Cu}$ pools and CopAl-like ATPases is necessary to attain high $\mathrm{Cu}$ resistance (Lee et al., 2002).

\section{PUTATIVE OUTER MEMBRANE CHANNEL: MctB}

MtcB (Rv1698) was first characterized as a high conductance channel located in the complex outer membrane of $M$. tuberculosis (Siroy et al., 2008). Expression of MctB in M. smegmatis resulted in an increased uptake of carbon source nutrients. While MctB structure is unknown, a functional analogy with Gram-negative porins has been suggested (Siroy et al., 2008). Analysis of the M. tuberculosis deletion mutant $\Delta m c t B$ showed decreased $\mathrm{Cu}^{+}$resistance and intracellular $\mathrm{Cu}^{+}$accumulation (Wolschendorf et al., 2011; Rowland and Niederweis, 2012). Importantly, infection experiments in mice and guinea pigs support the hypothesis that MctB is required for M. tuberculosis to attain maximal virulence (Wolschendorf et al., 2011). This is likely due to MctB's ability to counteract the bactericidal effect produced by the $\mathrm{Cu}^{+}$overload in activated macrophage phagosomes. Supplementary structural and biochemical studies might define the role of MctB in M. tuberculosis $\mathrm{Cu}^{+}$homeostasis and its interrelation with other $\mathrm{Cu}^{+}$efflux systems.

\section{CYTOPLASMIC Cu+ INFLUX}

Although the major $\mathrm{Cu}^{+}$efflux systems have been identified and well characterized, $\mathrm{Cu}^{+}$influx mechanisms are poorly understood. Early characterization of the E. coli ompB porin mutant showed a $\mathrm{Cu}$-resistant phenotype, suggesting that $\mathrm{Cu}^{+}$ may enter the cells through these outer membrane proteins (Lutkenhaus, 1977). Only recently has the participation of members of the MFS and TonB-dependent transport system in $\mathrm{Cu}$ import been proposed (see below). Based on phenotypic analysis, it was previously suggested that some $\mathrm{Cu}^{+}$-ATPases might drive metal influx (Odermatt et al., 1993; Koch et al., 2000; Tottey et al., 2001; Lewinson et al., 2009; Hassani et al., 2010). However, direct transport experiments and a better understanding of the $\mathrm{Cu}^{+}$-ATPase structure and transport mechanism have provided solid evidence that all $\mathrm{P}_{\mathrm{IB} 1}$-ATPases mediate $\mathrm{Cu}^{+}$efflux (González-Guerrero et al., 2010; Raimunda et al., 2011).

\section{Import of copper-chelating molecules}

Methane-oxidizing bacteria rely on two MMOs to achieve methanotrophic metabolism (Balasubramanian and Rosenzweig, 2008). The particulate pMMO is located in intracellular membranes and requires $\mathrm{Cu}$ for function. Thus, these organisms present an opportunity to identify specific $\mathrm{Cu}^{+}$-import mechanisms. Two pathways for $\mathrm{Cu}$ entry have been described in the methanotroph Methylosinus trichosporium (Balasubramanian et al., 2011). One of these, likely involved in $\mathrm{Cu}$-handling to $\mathrm{pMMO}$, requires the production of the siderophore-like methanobactin (Hakemian et al., 2005). The chalkophore structure is known and the $\mathrm{Cu}^{+}$binding capability extends to $\mathrm{Cu}$ removal from minerals (Hakemian et al., 2005; Knapp et al., 2007). Mechanistically, the holo-form is postulated to be taken up via an active TonB dependent transport mechanism (Balasubramanian et al., 2011). A less specific import pathway involves stripped or unchelated $\mathrm{Cu}^{+}$import via an outer membrane porin. However, this mechanism is not required for metallation of pMMO.

\section{Copper import catalyzed by secondary carriers}

Recently, a novel transporter has been identified based on its requirement for the metallation of cbb3-COX. R. capsulatus CcoA, a member of the MFS family, has been proposed to function as $\mathrm{Cu}$ importer (Ekici et al., 2012b). The MFS family consists of seventy-three sub-families of transporters that catalyze the symport, antiport or uniport of a wide variety of substrates, dissipating chemical or electrochemical gradients (Reddy et al., 2012). Like other MFS, CcoA is predicted to have twelve TM helices divided into two subdomains of six helices each and separated by a large cytoplasmic loop. Similar to the eukaryotic CTR-type $\mathrm{Cu}^{+}$-importers, CcoA contains several transmembrane Met rich motifs associated with $\mathrm{Cu}^{+}$binding and transport (Puig et al., 2002; Eisses and Kaplan, 2005; Ekici et al., 2012b). Importantly, mutation of a highly conserved tyrosine in the transmembrane YFLMLIFMT motif of the yeast CTR-type $\mathrm{Cu}^{+}$importer leads to a decrease in $\mathrm{Cu}^{+}$transport (Eisses and Kaplan, 2005). In the CcoA transporter, a similar sequence ( $\left.\mathrm{Y}^{230} \mathrm{ALMNLVMT}\right)$ is also present on the TM7 (Ekici et al., 2012b). Phenotypic characterization of $R$. capsulatus cells lacking a functional CcoA has implicated this transporter in $\mathrm{Cu}^{+}$import pathways, as well as in $\mathrm{Cu}^{+}$acquisition by $c b b 3-\mathrm{COX}$. Mutation of $R$. capsulatus $c c o A$ leads to a decrease in the total $\mathrm{Cu}^{+}$content of $R$. capsulatus and a decrease in the assembly and stability of the subunits of $c b b 3-\mathrm{COX}$ without inactivating the periplasmic MCO (CutO) (Ekici et al., 2012b). The similar phenotypic characteristics of the $P$. aeruginosa mutant $\triangle \operatorname{cop} A 2$ (missing the FixI/CopA2-like $\mathrm{Cu}^{+}$-ATPase) (González-Guerrero et al., 2010) and the R. capsulatus $\Delta c c o A$ mutant strains, together with their opposed direction of $\mathrm{Cu}^{+}$transport, support a model with COX metallation depending on the efflux of cytosolic $\mathrm{Cu}^{+}$(González-Guerrero et al., 2010; Ekici et al., 2012a). 


\section{CHAPERONES AND CHELATORS CYTOPLASMIC CHAPERONES}

Bacterial $\mathrm{Cu}^{+}$-chaperones, CopZs, are involved in cytoplasmic $\mathrm{Cu}^{+}$trafficking. Structurally, these proteins present a classic $\beta \alpha \beta \beta \alpha \beta$ ferredoxin-like folding with an invariant GXXCXXC $\mathrm{Cu}^{+}$-binding motif (Banci et al., 2004, 2010a,b; Boal and Rosenzweig, 2009). Extensive studies have shown their interaction with the regulatory $\mathrm{N}-\mathrm{MBD}$ of $\mathrm{Cu}^{+}$-ATPases, exchanging $\mathrm{Cu}^{+}$with $\mathrm{K}_{\mathrm{eq}} \approx 1$ (Argüello et al., 2007; Boal and Rosenzweig, 2009; Banci et al., 2010a,b; Robinson and Winge, 2010). Similarly, they exchange the metal with $\mathrm{Cu}^{+}$sensors (Cobine et al., 1999), and probably can receive the metal from bacterial $\mathrm{Cu}^{+}$importers. These interactions appear mediated by metal-dependent electrostatic interactions (Arnesano et al., 2001, 2002a; Boal and Rosenzweig, 2009; Banci et al., 2010a,b). An example of the importance of electrostatic interactions is the mechanism by which the CopZ loads $\mathrm{Cu}^{+}$substrates into transmembrane transport sites of $\mathrm{Cu}^{+}$-ATPases (González-Guerrero and Argüello, 2008; González-Guerrero et al., 2009; Argüello et al., 2011; Padilla-Benavides et al., 2013b). In this case, the electrostatic docking between the negatively charged surface of CopZ with the electropositive platform region of CopA directs the chaperone $\mathrm{Cu}^{+}$-binding residues toward the "entrance" of the TM-MBS (Gourdon et al., 2011; Padilla-Benavides et al., 2013b). As the ion moves within the enzyme to the TM-MBS, the chaperone is unable to receive the transported metal back from the enzyme.

A new role for $\mathrm{Cu}^{+}$-chaperones has been proposed in Halobacterium salinarum (Pang et al., 2013). In this organism, high $\mathrm{Cu}^{+}$induces temporal changes on transcription rates of two $\mathrm{Cu}^{+}$-chaperones and one $\mathrm{Cu}^{+}$-transporting ATPase through the activation of a Mer-like transcription factor. As observed previously in $P$. aeruginosa, the $\mathrm{Cu}^{+}$responsive metalloregulator is not up-regulated by $\mathrm{Cu}^{+}$(Teitzel et al., 2006; Raimunda et al., 2013). This, plus the fact that pools of small $\mathrm{Cu}^{+}$sequestering molecules like glutathione do not compete with the metalloregulator for $\mathrm{Cu}^{+}$(Changela et al., 2003), implies that a regulatory feedback involving physical interaction and $\mathrm{Cu}^{+}$transfer between the chaperones and the regulator might exist. The study proposed that one $\mathrm{CopZ}$ would play this role limiting $\mathrm{Cu}^{+}$access to the metalloregulator. This would allow the repression of the $\mathrm{Cu}^{+}$-transporting ATPase transcription, maintaining a hypothetically required intracellular $\mathrm{Cu}^{+}$quota. Accordingly, the cytosolic $\mathrm{Cu}^{+}$increase observed in $\mathrm{Cu}$ stressed chaperone mutant cells, points to a dual role of the chaperone participating in the sensing mechanisms (interaction with pools and metalloregulator) and delivering $\mathrm{Cu}^{+}$to the CopA1-like ATPase.

Finally, CupA, a novel membrane-bound $\mathrm{Cu}^{+}$chaperone was identified in Streptococcus pneumoniae (Fu et al., 2013). This pathogenic bacterium lacks the "classical" CopZ-type $\mathrm{Cu}^{+}$chaperone. The soluble domain of CupA is able to interact with and deliver $\mathrm{Cu}^{+}$to CopA N-MBD. Consequently, it was suggested to function as a membrane-bound $\mathrm{Cu}^{+}$-chaperone contributing to $\mathrm{Cu}^{+}$homeostasis. Surprisingly, CupA adopts a cupredoxin-like folding with a binuclear $\mathrm{Cu}$ site accessible and flexible enough to allow $\mathrm{Cu}^{+}$exchange. The finding of a folding more suited for electron transfer functions, instead of the classical ferredoxinlike observed in previously described bacterial $\mathrm{Cu}^{+}$-chaperones, is an intriguing variation that opens the possibility of novel functions.

\section{PERIPLASMIC CHAPERONES}

$\mathrm{Cu}$ distribution and dynamics in the periplasmic space are complex. The presence of different cuproenzymes such as azurin (Raimunda et al., 2013), CueO (Roberts et al., 2002), Cu/Zn-Sod (Gort et al., 1999), laccases (Claus, 2003), cytochrome $c$ oxidases (Richter and Ludwig, 2003), and tyrosinases (Claus and Decker, 2006) among other cuproproteins, exemplifies the vast diversity of periplasmic $\mathrm{Cu}^{+}$-binding proteins in different bacterial species (Figure 1). Although the function of these enzymes is fairly understood, the mechanisms underlying their metallation and $\mathrm{Cu}^{+}$traffic in this compartment require further studies. Experimental evidence has shown that both $\mathrm{Cu}^{+}$-ATPases and periplasmic chaperones, such as Thermus thermophilus $\mathrm{PCu}(\mathrm{A}) \mathrm{C}$ and $R$. capsulatus $\mathrm{Sco} / \mathrm{SenC}$, are required for the assembly of functional cytochrome $c$ oxidases (Swem et al., 2005; Abriata et al., 2008; González-Guerrero et al., 2010; Lohmeyer et al., 2012). However, the metal trafficking pathways from either the ATPases or the chaperones to the target proteins are not known. A similar novel example of $\mathrm{Cu}^{+}$trafficking within the periplasm is the metallation of S. enterica sv. Typhimurium SodCII (Osman et al., 2013). Here, the participation of the periplasmic chaperone CueP appears necessary. In this case, two $\mathrm{Cu}^{+}$-ATPases, CopA and GolT, seem able to provide $\mathrm{Cu}^{+}$for metallation of SodCII.

The role of the periplasmic chaperone CusF, associated with the CusCFBA efflux system, in the efflux of periplasmic $\mathrm{Cu}^{+}$ has also been described. CusF interacts with and delivers $\mathrm{Cu}^{+}$to CusB, which will further translocate the metal to the extracellular milieu (Mealman et al., 2011). Less is known about the periplasmic $\mathrm{Cu}^{+}$-chaperones from the Pco system. Bioinformatics analysis suggests the existence of two periplasmic chaperones: PcoA and PcoC. PcoA is a MCO (Djoko et al., 2008) that may functionally replace $\mathrm{CueO}$ in some bacterial systems where $\mathrm{CueO}$ is not present (Hernández-Montes et al., 2012) or under microaerobiosis, when this enzyme is not active (Outten et al., 2001; Rensing and Grass, 2003). Double mutation of cueO and cusCFBA in E. coli GR10 cells rendered a hypersensitive response to $\mathrm{Cu}^{+}$; complementation of this strain with a plasmid encoding for $p c o A$ restored $\mathrm{Cu}^{+}$tolerance of these cells (Lee et al., 2002). No specific function has been proposed for PcoC, though this putative periplasmic protein binds one $\mathrm{Cu}^{+}$-equivalent (Lee et al., 2002). Whether or not these chaperones interact with the putative transporting components of the Pco system (PcoB and PcoD) remains to be elucidated. It is evident that within the bacterial periplasm, a vast diversity of periplasmic chaperones and enzymes have fundamental roles in maintaining $\mathrm{Cu}^{+}$homeostasis in coordination with the different efflux and influx systems. Thus, highlighting the necessity of further experimental and metalloproteomics integrative studies.

\section{OTHER CYTOPLASMIC CHELATORS AND UNCHARACTERIZED BACTERIAL COPPER POOLS}

How much $\mathrm{Cu}^{+}$in the surrounding environment can a cell withstand? Gram-negative bacteria, such as P. aeruginosa and E. coli, replicate at normal rates when grown at high $\mathrm{Cu}^{+}$concentrations 
(1-2 mM). Such high $\mathrm{Cu}^{+}$tolerance might be explained by the fact that bioavailable $\mathrm{Cu}^{+}$(or $\mathrm{Cu}^{+}$available in the media) might be several orders of magnitude below that range. However, cells could take up chelated-Cu${ }^{+}$as a silent piggyback rider while bound to nutrients or, more likely, by specialized $\mathrm{Cu}^{+}$import systems after being stripped off the ligand molecule by specific exchange reactions. Both mechanisms would secure the $\mathrm{Cu}^{+}$ quota. However, the second mode of $\mathrm{Cu}^{+}$entry would require the proper storage and sorting once $\mathrm{Cu}^{+}$reaches the cytoplasm. In this regard, there is a lack of information on the constituents and sizes of $\mathrm{Cu}^{+}$pools in the cell. Interestingly, it has been shown that oxidative and nitrosative stress, conditions where $\mathrm{Cu}$ plays a central role as part of the stress-tolerance machinery, triggers synthesis of cytosolic metallothioneins (Gold et al., 2008) and other extracellular cuproproteins (Raimunda et al., 2013). Thus, these proteins might have important functions not only in $\mathrm{Cu}^{+}$storage, but also in sensing mechanisms. Recent work in $H$. salinarum suggests an interplay between $\mathrm{Cu}$ pools and $\mathrm{Cu}^{+}$-chaperones with relevant implications in $\mathrm{Cu}^{+}$homeostasis (Pang et al., 2013).

\section{TOWARD INTEGRATION}

Previous sections have described the different elements participating in $\mathrm{Cu}$ homeostasis, including not only those that move the ion within and across compartments, but the various cuproproteins that require the metal for function. The requirement to maintain the cell free of $\mathrm{Cu}^{+}$determines that the metal is transferred and delivered to final targets via chelator/protein-protein interactions. The molecular details of some of these events are not well understood and are just started to be uncovered. Similarly, although numerous examples are recorded in the literature, the presence of alternative arrangements of transporters and chelators has not been considered in an integrated fashion. These aspects are discussed in the following sections.

\section{ACHIEVING SELECTIVITY: $\mathrm{Cu}^{+}$-ATPASES AND CHAPERONES}

As pointed out, it is accepted that $\mathrm{Cu}^{+}$ions are not free in cellular systems because of the high affinity binding of chaperone, sensing, and transport proteins. It is clear that these "high affinities" are for $\mathrm{Cu}^{+}$binding/release into the aqueous media and they do not represent the molecular affinity for $\mathrm{Cu}^{+}$when the ion is located at the interacting interphase of two partner proteins "exchanging" $\mathrm{Cu}^{+}$. Thus, $\mathrm{Cu}^{+}$dependent protein-protein recognition is key for selectivity. An example of this phenomenon is the $\mathrm{Cu}^{+}$transfer from the cytoplasmic chaperones to the TM-MBS of transport ATPases. In this case, the specific electrostatic complementation of the $\mathrm{Cu}^{+}$-bound chaperone with ATPase appears to determine the interaction (Padilla-Benavides et al., 2013b). As a consequence, structurally similar MBDs carrying a different electrostatic surface cannot deliver $\mathrm{Cu}^{+}$to the ATPase nor can the apo-form of the chaperone "compete" with its holo-form (González-Guerrero and Argüello, 2008).

This parsimonious model might, however, be challenged in organisms with more than one $\mathrm{Cu}^{+}$-ATPase gene (PadillaBenavides et al., 2013b). Thus, it could be hypothesized that in the genomes of organisms with more than one $\mathrm{Cu}^{+}$-ATPase gene might also contain genes for different $\mathrm{Cu}^{+}$-chaperones. Additionally, there may be alternative small proteins or other molecules that deliver $\mathrm{Cu}^{+}$for transport through a particular ATPase.

\section{ACHIEVING SELECTIVITY: TRANSPORTERS AS TARGETING MECHANISMS}

While protein-protein interaction is a likely determinant for compartmental $\mathrm{Cu}^{+}$distribution to various target molecules, directing $\mathrm{Cu}^{+}$through distinct transporters also appears to play a central role (Figure 1). An example is again provided by alternative roles described for $\mathrm{Cu}^{+}$-ATPases. Bacterial genomes contain at least one gene encoding for a $\mathrm{Cu}^{+}$-ATPase, which is essential in conferring $\mathrm{Cu}^{+}$tolerance (Rensing and Grass, 2003; Osman and Cavet, 2008; Argüello et al., 2011). However, the presence of multiple $\mathrm{Cu}^{+}$-ATPase coding genes in some genomes suggests their participation in different cellular processes. The idea of redundancy conferring reliability has been considered to understand the presence of multiple $\mathrm{Cu}^{+}$-ATPases. However, this increases complexity and energetic cost. In some cases, such as Salmonella, phenotypical and functional differences amongst two $\mathrm{Cu}^{+}$-ATPases, CopA and GolT, are a matter of debate (Checa et al., 2007; Osman et al., 2010). However, new subgroups of functionally distinct, non-redundant $\mathrm{Cu}^{+}$-ATPases have been described (Raimunda et al., 2011).

For instance, the $P$. aeruginosa genome encodes for two nonredundant $\mathrm{Cu}^{+}$-ATPases: CopA1 and CopA2 (Figure 1). CopA1 is the classical $\mathrm{Cu}^{+}$-ATPase, and its deletion leads to $\mathrm{Cu}^{+}$accumulation and sensitivity for this metal. CopA2 presents slow kinetics of transport and higher affinity for $\mathrm{Cu}^{+}$than that the observed in classic $\mathrm{Cu}^{+}$detoxifying enzymes (González-Guerrero et al., 2010). This slow rate of transport is incompatible with a role in $\mathrm{Cu}^{+}$-detoxification but seems adequate to contribute to the assembly of cuproproteins. CopA2/FixI-like ATPases are co-transcribed with COX subunits. As such, it has been demonstrated that in $P$. aeruginosa CopA2 is required for the activity of this cuproprotein (González-Guerrero et al., 2010). One question immediately emerges, beyond these frequently observed functions $\left(\mathrm{Cu}^{+}\right.$detoxification and COX metallation) should we expect the distinct participation of $\mathrm{Cu}^{+}$-ATPases in other processes? Considering the presence of up to five $\mathrm{Cu}^{+}$-ATPase genes in certain bacterial genomes, it is tempting to hypothesize that unique/specific roles determined by their kinetic characteristics and structural determinants will emerge for each. As a corollary, if each $\mathrm{Cu}^{+}$-ATPase has a distinct function the simultaneous presence of multiple periplasmic chaperones serving different subgroups of cuproproteins is also necessary. In this hypothetical model, the presence of multiple cytoplasmic $\mathrm{Cu}^{+}$-chaperones might also be expected.

\section{ALTERNATIVE ARCHITECTURES FOR Cu+ EFFLUX SYSTEMS: COPPER HOMEOSTASIS IN $\gamma$-PROTEOBACTERIA}

Analysis of $\mathrm{Cu}$ transport and distribution in various bacteria has shown the frequent presence of polycistronic "transport systems" (See Maintaining the $\mathrm{Cu}^{+}$quota: $\mathrm{Cu}^{+}$-sensing and transcriptional regulation of homeostatic systems). Recent bioinformatics analyses of systems involved in periplasmic homeostasis have shown that only $3 \%$ of the available $\gamma$-proteobacteria genomes present the full set of $\mathrm{Cu}$ homeostasis systems previously 
described (Rensing and Grass, 2003; Osman and Cavet, 2008; Hernández-Montes et al., 2012). That is, the vast majority of the organisms analyzed lack one or more components in one of these systems. While the $\mathrm{Cu}^{+}$-ATPases appear universal, the presence of other components seems to cluster in independent groups or clades: CueP, PcoC-YebZ-CutF-CusF-CueO, PcoE-PcoD, PcoA$\mathrm{PcoB}$, and CusC-CusA-CusB. This suggests that, depending on the presence or absence of some components, bacteria achieve $\mathrm{Cu}$ homeostasis through different strategies (Hernández-Montes et al., 2012). Since the selective pressure produced by the host immune system favored and preserved these detoxification mechanisms, it is not surprising that some pathogenic bacteria, such as Klebsiella pneumonia, Enterobacter cloacae, E. coli, Cronobacter sakazakii, and Cronobacter turicensis, carry the largest amount of proteins required for $\mathrm{Cu}$ homeostasis in their genomes (Hernández-Montes et al., 2012). Importantly, the linkage among components seems evolutionarily driven by protein-protein interactions rather than by function. For instance, CusC is distributed independently of CusB and CusA, as it is the most encountered protein after CopA in the clades. Alternatively, CueP was found in organisms also containing CusCFBA, arguing against the hypothesis that the former compensates for the latter in Salmonella. This presents challenges to any integrative parsimonious description of $\mathrm{Cu}$ homeostasis.

\section{FUTURE DIRECTIONS}

Significant insights into the metal selectivity, regulation, transport mechanism, and interaction with metallochaperones have been gained. The high-resolution crystal structure of the $\mathrm{Cu}^{+}$ATPase, various cytoplasmic and periplasmic chaperones, $\mathrm{Cu}^{+}$ sensors, and several components of the Cus system, as well as their biochemical characterization, has contributed to the elucidation of structure-function relationships in these molecules. The interaction between cytosolic $\mathrm{Cu}^{+}$chaperones with the ATPases, as well as the access of $\mathrm{Cu}^{+}$to the TM-MBSs, is relatively well understood. However, little information is available on the interaction of chaperones and sensors, or how the chaperones obtain $\mathrm{Cu}^{+}$from their transmembrane transporters and subsequently deliver it to cuproenzymes. Despite the fact that biochemical studies will soon target these questions, a higher order of integration appears necessary to understand the homeostasis of this micronutrient. While global transcriptomics studies have provided some progress toward this goal, it appears that establishing the total composition of the cuproproteomes is an important requirement. Subsequently, a systems biology analysis, taking into account $\mathrm{Cu}^{+}$ pools sizes, their kinetics and thermodynamics, seems to be the next logical step.

\section{ACKNOWLEDGMENTS}

This work was supported by National Science Foundation Grant MCB-0743901 (to José M. Argüello).

\section{REFERENCES}

Abriata, L. A., Banci, L., Bertini, I., Ciofi-Baffoni, S., Gkazonis, P., Spyroulias, G. A., et al. (2008). Mechanism of $\mathrm{Cu}(\mathrm{A})$ assembly. Nat. Chem. Biol. 4, 599-601. doi: $10.1038 /$ nchembio. 110

Adman, E. T. (1991). Copper protein structures. Adv. Protein Chem. 42, 145-197. doi: 10.1016/S0065-3233(08)60536-7
Argüello, J. M. (2003). Identification of ion-selectivity determinants in heavy-metal transport $\mathrm{P}_{1 \mathrm{~B}}$-type ATPases. J. Membr. Biol. 195, 93-108. doi: 10.1007/s00232003-2048-2

Argüello, J. M., Eren, E., and González-Guerrero, M. (2007). The structure and function of heavy metal transport $\mathrm{P}_{1 \mathrm{~B}}$-ATPases. Biometals 20, 233-248. doi: 10.1007/s10534-006-9055-6

Argüello, J. M., González-Guerrero, M., and Raimunda, D. (2011). Bacterial transition metal $\mathrm{P}_{1 \mathrm{~B}}$-ATPases: transport mechanism and roles in virulence. Biochemistry 50, 9940-9949. doi: 10.1021/bi201418k

Argüello, J. M., Raimunda, D., and González-Guerrero, M. (2012). Metal transport across biomembranes: emerging models for a distinct chemistry. J. Biol. Chem. 287, 13510-13517. doi: 10.1074/jbc.R111.319343

Arnesano, F., Banci, L., Bertini, I., Cantini, F., Ciofi-Baffoni, S., Huffman, D. L., et al. (2001). Characterization of the binding interface between the copper chaperone Atx1 and the first cytosolic domain of Ccc2 ATPase. J. Biol. Chem. 276, 41365-41376. doi: 10.1074/jbc.M104807200

Arnesano, F., Banci, L., Bertini, I., Ciofi-Baffoni, S., Molteni, E., Huffman, D. L., et al. (2002a). Metallochaperones and metal-transporting ATPases: a comparative analysis of sequences and structures. Genome Res. 12, 255-271. doi: 10.1101/gr.196802

Arnesano, F., Banci, L., Bertini, I., and Thompsett, A. R. (2002b). Solution structure of CopC: a cupredoxin-like protein involved in copper homeostasis. Structure 10, 1337-1347. doi: 10.1016/S0969-2126(02)00858-4

Arnesano, F., Banci, L., Bertini, I., Mangani, S., and Thompsett, A. R. (2003). A redox switch in CopC: an intriguing copper trafficking protein that binds copper(I) and copper(II) at different sites. Proc. Natl. Acad. Sci. U.S.A. 100, 3814-3819. doi: 10.1073/pnas.0636904100

Balasubramanian, R., Kenney, G. E., and Rosenzweig, A. C. (2011). Dual pathways for copper uptake by methanotrophic bacteria. J. Biol. Chem. 286, 37313-37319. doi: 10.1074/jbc.M111.284984

Balasubramanian, R., and Rosenzweig, A. C. (2008). Copper methanobactin: a molecule whose time has come. Curr. Opin. Chem. Biol. 12, 245-249. doi: 10.1016/j.cbpa.2008.01.043

Banci, L., Bertini, I., Cantini, F., and Ciofi-Baffoni, S. (2010a). Cellular copper distribution: a mechanistic systems biology approach. Cell. Mol. Life Sci. 67, 2563-2589. doi: 10.1007/s00018-010-0330-x

Banci, L., Bertini, I., McGreevy, K. S., and Rosato, A. (2010b). Molecular recognition in copper trafficking. Nat. Prod. Rep. 27, 695-710. doi: 10.1039/b906678k

Banci, L., Bertini, I., Ciofi-Baffoni, S., Kozyreva, T., Mori, M., and Wang, S. (2011). Sco proteins are involved in electron transfer processes. J. Biol. Inorg. Chem. 16, 391-403. doi: 10.1007/s00775-010-0735-x

Banci, L., Bertini, I., Ciofi-Baffoni, S., Su, X. C., Borrelly, G. P., and Robinson, N. J. (2004). Solution structures of a cyanobacterial metallochaperone: insight into an atypical copper-binding motif. J. Biol. Chem. 279, 27502-27510. doi: 10.1074/jbc.M402005200

Basu, P., Katterle, B., Andersson, K. K., and Dalton, H. (2003). The membraneassociated form of methane mono-oxygenase from Methylococcus capsulatus (Bath) is a copper/iron protein. Biochem. J. 369(Pt 2), 417-427. doi: $10.1042 /$ BJ20020823

Bender, C. L., and Cooksey, D. A. (1986). Indigenous plasmids in Pseudomonas syringae pv. tomato: conjugative transfer and role in copper resistance. J. Bacteriol. 165, 534-541.

Berks, B. C., Palmer, T., and Sargent, F. (2003). The Tat protein translocation pathway and its role in microbial physiology. Adv. Microb. Physiol. 47, 187-254. doi: 10.1016/S0065-2911(03)47004-5

Berks, B. C., Sargent, F., De Leeuw, E., Hinsley, A. P., Stanley, N. R., Jack, R. L., et al. (2000a). A novel protein transport system involved in the biogenesis of bacterial electron transfer chains. Biochim. Biophys. Acta 1459, 325-330. doi: 10.1016/S0005-2728(00)00168-7

Berks, B. C., Sargent, F., and Palmer, T. (2000b). The Tat protein export pathway. Mol. Microbiol. 35, 260-274. doi: 10.1046/j.1365-2958.2000.01719.x

Bjorklof, K., Zickermann, V., and Finel, M. (2000). Purification of the $45 \mathrm{kDa}$, membrane bound NADH dehydrogenase of Escherichia coli (NDH-2) and analysis of its interaction with ubiquinone analogues. FEBS Lett. 467, 105-110. doi: 10.1016/S0014-5793(00)01130-3

Boal, A. K., and Rosenzweig, A. C. (2009). Structural biology of copper trafficking. Chem. Rev. 109, 4760-4779. doi: 10.1021/cr900104z

Braunstein, M., Espinosa, B. J., Chan, J., Belisle, J. T., and Jacobs, W. R. Jr. (2003). SecA2 functions in the secretion of superoxide dismutase $A$ and in the virulence 
of Mycobacterium tuberculosis. Mol. Microbiol. 48, 453-464. doi: 10.1046/j.13652958.2003.03438.x

Brown, K., Tegoni, M., Prudencio, M., Pereira, A. S., Besson, S., Moura, J. J., et al. (2000). A novel type of catalytic copper cluster in nitrous oxide reductase. Nat. Struct. Biol. 7, 191-195. doi: 10.1038/73288

Brown, N. L., Barrett, S. R., Camakaris, J., Lee, B. T., and Rouch, D. A. (1995). Molecular genetics and transport analysis of the copper-resistance determinant (pco) from Escherichia coli plasmid pRJ1004. Mol. Microbiol. 17, 1153-1166. doi: 10.1111/j.1365-2958.1995.mmi_17061153.x

Brown, N. L., Stoyanov, J. V., Kidd, S. P., and Hobman, J. L. (2003). The MerR family of transcriptional regulators. FEMS Microbiol. Rev. 27, 145-163. doi: 10.1016/S0168-6445(03)00051-2

Cha, J. S., and Cooksey, D. A. (1991). Copper resistance in Pseudomonas syringae mediated by periplasmic and outer membrane proteins. Proc. Natl. Acad. Sci. U.S.A. 88, 8915-8919. doi: 10.1073/pnas.88.20.8915

Cha, J. S., and Cooksey, D. A. (1993). Copper hypersensitivity and uptake in Pseudomonas syringae containing cloned components of the copper resistance operon. Appl. Environ. Microbiol. 59, 1671-1674.

Changela, A., Chen, K., Xue, Y., Holschen, J., Outten, C. E., O’Halloran, T. V., et al. (2003). Molecular basis of metal-ion selectivity and zeptomolar sensitivity by CueR. Science 301, 1383-1387. doi: 10.1126/science.1085950

Checa, S. K., Espariz, M., Audero, M. E., Botta, P. E., Spinelli, S. V., and Soncini, F. C. (2007). Bacterial sensing of and resistance to gold salts. Mol. Microbiol. 63, 1307-1318. doi: 10.1111/j.1365-2958.2007.05590.x

Chen, L. Y., Chen, M. Y., Leu, W. M., Tsai, T. Y., and Lee, Y. H. (1993). Mutational study of Streptomyces tyrosinase trans-activator MelC1. MelC1 is likely a chaperone for apotyrosinase. J. Biol. Chem. 268, 18710-18716.

Chen, L. Y., Leu, W. M., Wang, K. T., and Lee, Y. H. W. (1992). Copper transfer and activation of the Streptomyces apotyrosinase are mediated through a complexformation between apotyrosinase and its transactivator Melcl. J. Biol. Chem. 267, 20100-20107.

Chillappagari, S., Miethke, M., Trip, H., Kuipers, O. P., and Marahiel, M. A. (2009). Copper acquisition is mediated by YcnJ and regulated by YcnK and CsoR in Bacillus subtilis. J. Bacteriol. 191, 2362-2370. doi: 10.1128/JB. 01616-08

Claus, H. (2003). Laccases and their occurrence in prokaryotes. Arch. Microbiol. 179, 145-150. doi: 10.1007/s00203-002-0510-7

Claus, H., and Decker, H. (2006). Bacterial tyrosinases. Syst. Appl. Microbiol. 29, 3-14. doi: 10.1016/j.syapm.2005.07.012

Cobine, P., Wickramasinghe, W. A., Harrison, M. D., Weber, T., Solioz, M., and Dameron, C. T. (1999). The Enterococcus hirae copper chaperone CopZ delivers copper(I) to the CopY repressor. FEBS Lett. 445, 27-30. doi: 10.1016/S00145793(99)00091-5

Cobine, P. A., Pierrel, F., and Winge, D. R. (2006). Copper trafficking to the mitochondrion and assembly of copper metalloenzymes. Biochim. Biophys. Acta 1763, 759-772. doi: 10.1016/j.bbamcr.2006.03.002

Cooksey, D. A. (1987). Characterization of a copper resistance plasmid conserved in copper-resistant strains of Pseudomonas syringae pv. tomato. Appl. Environ. Microbiol. 53, 454-456.

Cooksey, D. A. (1990). Plasmid-determined copper resistance in Pseudomonas syringae from impatiens. Appl. Environ. Microbiol. 56, 13-16.

Cooksey, D. A. (1993). Copper uptake and resistance in bacteria. Mol. Microbiol. 7, 1-5. doi: 10.1111/j.1365-2958.1993.tb01091.x

Corbett, D., Schuler, S., Glenn, S., Andrew, P. W., Cavet, J. S., and Roberts, I. S. (2011). The combined actions of the copper-responsive repressor CsoR and copper-metallochaperone CopZ modulate CopA-mediated copper efflux in the intracellular pathogen Listeria monocytogenes. Mol. Microbiol. 81, 457-472. doi: 10.1111/j.1365-2958.2011.07705.x

Cvetkovic, A., Menon, A. L., Thorgersen, M. P., Scott, J. W., Poole, F. L. 2nd., Jenney, F. E. Jr., et al. (2010). Microbial metalloproteomes are largely uncharacterized. Nature 466, 779-782. doi: 10.1038/nature09265

De Rienzo, F., Gabdoulline, R. R., Menziani, M. C., and Wade, R. C. (2000). Blue copper proteins: a comparative analysis of their molecular interaction properties. Protein Sci. 9, 1439-1454. doi: 10.1110/ps.9.8.1439

Djoko, K. Y., Xiao, Z., and Wedd, A. G. (2008). Copper resistance in E. coli: the multicopper oxidase PcoA catalyzes oxidation of copper(I) in $\mathrm{Cu}(\mathrm{I}) \mathrm{Cu}(\mathrm{II})-\mathrm{PcoC}$. Chem. Biochem. 9, 1579-1582. doi: 10.1002/cbic.200800100

Donaire, A., Jimenez, B., Fernandez, C. O., Pierattelli, R., Niizeki, T., Moratal, J. M., et al. (2002). Metal-ligand interplay in blue copper proteins studied by $1 \mathrm{H}$
NMR spectroscopy: $\mathrm{Cu}(\mathrm{II})$-pseudoazurin and $\mathrm{Cu}(\mathrm{II})$-rusticyanin. J. Am. Chem. Soc. 124, 13698-13708. doi: 10.1021/ja0267019

Dupont, C. L., Grass, G., and Rensing, C. (2011). Copper toxicity and the origin of bacterial resistance-new insights and applications. Metallomics 3, 1109-1118. doi: $10.1039 / \mathrm{clmt} 00107 \mathrm{~h}$

Eisses, J. F., and Kaplan, J. H. (2005). The mechanism of copper uptake mediated by human CTR1: a mutational analysis. J. Biol. Chem. 280, 37159-37168. doi: 10.1074/jbc.M508822200

Ekici, S., Pawlik, G., Lohmeyer, E., Koch, H. G., and Daldal, F. (2012a). Biogenesis of cbb(3)-type cytochrome c oxidase in Rhodobacter capsulatus. Biochim. Biophys. Acta 1817, 898-910. doi: 10.1016/j.bbabio.2011.10.011

Ekici, S., Yang, H., Koch, H. G., and Daldal, F. (2012b). Novel transporter required for biogenesis of cbb3-type cytochrome c oxidase in Rhodobacter capsulatus. MBio 3:e00293-00211. doi: 10.1128/mBio.00293-11

Elguindi, J., Wagner, J., and Rensing, C. (2009). Genes involved in copper resistance influence survival of Pseudomonas aeruginosa on copper surfaces. J. Appl. Microbiol. 106, 1448-1455. doi: 10.1111/j.1365-2672.2009.04148.x

Espariz, M., Checa, S. K., Audero, M. E., Pontel, L. B., and Soncini, F. C. (2007). Dissecting the Salmonella response to copper. Microbiology 153(Pt 9), 2989-2997. doi: 10.1099/mic.0.2007/006536-0

Fang, F. C., DeGroote, M. A., Foster, J. W., Baumler, A. J., Ochsner, U., Testerman, T., et al. (1999). Virulent Salmonella typhimurium has two periplasmic $\mathrm{Cu}$, Zn-superoxide dismutases. Proc. Natl. Acad. Sci. U.S.A. 96, 7502-7507. doi: 10.1073/pnas.96.13.7502

Franke, S., Grass, G., and Nies, D. H. (2001). The product of the ybdE gene of the Escherichia coli chromosome is involved in detoxification of silver ions. Microbiology 147(Pt 4), 965-972.

Franke, S., Grass, G., Rensing, C., and Nies, D. H. (2003). Molecular analysis of the copper-transporting efflux system CusCFBA of Escherichia coli. J. Bacteriol. 185, 3804-3812. doi: 10.1128/JB.185.13.3804-3812.2003

Fu, Y., Tsui, H. C., Bruce, K. E., Sham, L. T., Higgins, K. A., Lisher, J. P., et al. (2013). A new structural paradigm in copper resistance in Streptococcus pneumoniae. Nat. Chem. Biol. 9, 177-183. doi: 10.1038/nchembio.1168

Gaetke, L. M., and Chow, C. K. (2003). Copper toxicity, oxidative stress, and antioxidant nutrients. Toxicology 189, 147-163. doi: 10.1016/S0300-483X(03)00159-8

Garcia-Horsman, J. A., Barquera, B., Rumbley, J., Ma, J., and Gennis, R. B. (1994). The superfamily of heme-copper respiratory oxidases. J. Bacteriol. 176, 5587-5600.

Gladyshev, V. N., and Zhang, Y. (2013). Comparative genomics analysis of the metallomes. Met. Ions Life Sci. 12, 529-580. doi: 10.1007/978-94-007-5561-1_16

Godden, J. W., Turley, S., Teller, D. C., Adman, E. T., Liu, M. Y., Payne, W. J., et al. (1991). The 2.3 angstrom X-ray structure of nitrite reductase from Achromobacter cycloclastes. Science 253, 438-442. doi: 10.1126/science.1862344

Gold, B., Deng, H., Bryk, R., Vargas, D., Eliezer, D., Roberts, J., et al. (2008). Identification of a copper-binding metallothionein in pathogenic mycobacteria. Nat. Chem. Biol. 4, 609-616. doi: 10.1038/nchembio.109

González-Guerrero, M., and Argüello, J. M. (2008). Mechanism of $\mathrm{Cu}^{+}$. transporting ATPases: soluble $\mathrm{Cu}^{+}$chaperones directly transfer $\mathrm{Cu}^{+}$to transmembrane transport sites. Proc. Natl. Acad. Sci. U.S.A. 105, 5992-5997. doi: 10.1073/pnas.0711446105

González-Guerrero, M., Eren, E., Rawat, S., Stemmler, T. L., and Argüello, J. M. (2008). Structure of the two transmembrane $\mathrm{Cu}^{+}$transport sites of the $\mathrm{Cu}^{+}$ATPases. J. Biol. Chem. 283, 29753-29759. doi: 10.1074/jbc.M803248200

González-Guerrero, M., Hong, D., and Argüello, J. M. (2009). Chaperone-mediated $\mathrm{Cu}^{+}$delivery to $\mathrm{Cu}^{+}$transport ATPases: requirement of nucleotide binding. J. Biol. Chem. 284, 20804-20811. doi: 10.1074/jbc.M109.016329

González-Guerrero, M., Raimunda, D., Cheng, X., and Argüello, J. M. (2010). Distinct functional roles of homologous $\mathrm{Cu}^{+}$efflux ATPases in Pseudomonas aeruginosa. Mol. Microbiol. 78, 1246-1258. doi: 10.1111/j.13652958.2010.07402.x

Gort, A. S., Ferber, D. M., and Imlay, J. A. (1999). The regulation and role of the periplasmic copper, zinc superoxide dismutase of Escherichia coli. Mol. Microbiol. 32, 179-191. doi: 10.1046/j.1365-2958.1999.01343.x

Gourdon, P., Liu, X. Y., Skjorringe, T., Morth, J. P., MØller, L. B., Pedersen, B. P., et al. (2011). Crystal structure of a copper-transporting PIB-type ATPase. Nature 475, 59-U74. doi: 10.1038/nature10191

Grass, G., and Rensing, C. (2001). CueO is a multi-copper oxidase that confers copper tolerance in Escherichia coli. Biochem. Biophys. Res. Commun. 286, 902-908. doi: 10.1006/bbrc.2001.5474 
Gudipaty, S. A., Larsen, A. S., Rensing, C., and McEvoy, M. M. (2012). Regulation of $\mathrm{Cu}(\mathrm{I}) / \mathrm{Ag}(\mathrm{I})$ efflux genes in Escherichia coli by the sensor kinase CusS. FEMS Microbiol. Lett. 330, 30-37. doi: 10.1111/j.1574-6968.2012.02529.x

Gupta, A., Phung, L. T., Taylor, D. E., and Silver, S. (2001). Diversity of silver resistance genes in IncH incompatibility group plasmids. Microbiology 147(Pt 12), 3393-3402.

Hakemian, A. S., Tinberg, C. E., Kondapalli, K. C., Telser, J., Hoffman, B. M., Stemmler, T. L., et al. (2005). The copper chelator methanobactin from Methylosinus trichosporium OB3b binds copper(I). J. Am. Chem. Soc. 127, 17142-17143. doi: 10.1021/ja0558140

Hassani, B. K., Astier, C., Nitschke, W., and Ouchane, S. (2010). CtpA, a copper-translocating P-type ATPase involved in the biogenesis of multiple copper-requiring enzymes. J. Biol. Chem. 285, 19330-19337. doi: 10.1074/jbc.M110.116020

Hemsworth, G. R., Taylor, E. J., Kim, R. Q., Gregory, R. C., Lewis, S. J., Turkenburg, J. P., et al. (2013). The copper active site of CBM33 polysaccharide oxygenases. J. Am. Chem. Soc. 135, 6069-6077. doi: 10.1021/ja402106e

Hernández-Montes, G., Argüello, J. M., and Valderrama, B. (2012). Evolution and diversity of periplasmic proteins involved in copper homeostasis in gamma proteobacteria. BMC Microbiol. 12, 249-263. doi: 10.1186/1471-218012-249

Hintermann, G., Zatchej, M., and Hutter, R. (1985). Cloning and expression of the genetically unstable tyrosinase structural gene from Streptomyces glaucescens. Mol. Gen. Genet. 200, 422-432. doi: 10.1007/BF00425726

Huber, M., Hintermann, G., and Lerch, K. (1985). Primary structure of tyrosinase from Streptomyces glaucescens. Biochemistry 24, 6038-6044. doi: 10.1021/bi00343a003

Ikeda, K., Masujima, T., Suzuki, K., and Sugiyama, M. (1996). Cloning and sequence analysis of the highly expressed melanin-synthesizing gene operon from Streptomyces castaneoglobisporus. Appl. Microbiol. Biotechnol. 45, 80-85. doi: $10.1007 / \mathrm{s} 002530050652$

Imlay, K. R., and Imlay, J. A. (1996). Cloning and analysis of sodC, encoding the copper-zinc superoxide dismutase of Escherichia coli. J. Bacteriol. 178, 2564-2571.

Jaworowski, A., Mayo, G., Shaw, D. C., Campbell, H. D., and Young, I. G. (1981). Characterization of the respiratory NADH dehydrogenase of Escherichia coli and reconstitution of NADH oxidase in ndh mutant membrane vesicles. Biochemistry 20, 3621-3628. doi: 10.1021/bi00515a049

Joshi, C. P., Panda, D., Martell, D. J., Andoy, N. M., Chen, T. Y., Gaballa, A., et al. (2012). Direct substitution and assisted dissociation pathways for turning off transcription by a MerR-family metalloregulator. Proc. Natl. Acad. Sci. U.S.A. 109, 15121-15126. doi: 10.1073/pnas.1208508109

Kaim, W., and Rall, J. (1996). Copper-a "modern" bioelement. Angew. Chem. Int. Ed. 35, 43-60. doi: 10.1002/anie.199600431

Katz, E., Thompson, C. J., and Hopwood, D. A. (1983). Cloning and expression of the tyrosinase gene from Streptomyces antibioticus in Streptomyces lividans. J. Gen. Microbiol. 129, 2703-2714. doi: 10.1099/00221287-129-9-2703

Kim, E. H., Nies, D. H., McEvoy, M. M., and Rensing, C. (2011). Switch or funnel: how RND-type transport systems control periplasmic metal homeostasis. J. Bacteriol. 193, 2381-2387. doi: 10.1128/JB.01323-10

Knapp, C. W., Fowle, D. A., Kulczycki, E., Roberts, J. A., and Graham, D. W. (2007). Methane monooxygenase gene expression mediated by methanobactin in the presence of mineral copper sources. Proc. Natl. Acad. Sci. U.S.A. 104, 12040-12045. doi: 10.1073/pnas.0702879104

Koch, H. G., Winterstein, C., Saribas, A. S., Alben, J. O., and Daldal, F. (2000). Roles of the ccoGHIS gene products in the biogenesis of the cbb(3)-type cytochrome c oxidase. J. Mol. Biol. 297, 49-65. doi: 10.1006/jmbi.2000.3555

Krishnakumar, R., Kim, B., Mollo, E. A., Imlay, J. A., and Slauch, J. M. (2007). Structural properties of periplasmic SodCI that correlate with virulence in Salmonella enterica serovar Typhimurium. J. Bacteriol. 189, 4343-4352. doi: 10.1128/JB.00010-07

Kroll, J. S., Langford, P. R., Wilks, K. E., and Keil, A. D. (1995). Bacterial $[\mathrm{Cu}, \mathrm{Zn}]$-superoxide dismutase: phylogenetically distinct from the eukaryotic enzyme, and not so rare after all! Microbiology 141(Pt 9), 2271-2279. doi: 10.1099/13500872-141-9-2271

Lee, S. M., Grass, G., Rensing, C., Barrett, S. R., Yates, C. J., Stoyanov, J. V., et al. (2002). The Pco proteins are involved in periplasmic copper handling in Escherichia coli. Biochem. Biophys. Res. Commun. 295, 616-620. doi: 10.1016/S0006-291X(02)00726-X
Levasseur, A., Drula, E., Lombard, V., Coutinho, P. M., and Henrissat, B. (2013). Expansion of the enzymatic repertoire of the CAZy database to integrate auxiliary redox enzymes. Biotechnol. Biofuels 6, 41-55. doi: 10.1186/17546834-6-41

Lewinson, O., Lee, A. T., and Rees, D. C. (2009). A P-type ATPase importer that discriminates between essential and toxic transition metals. Proc. Natl. Acad. Sci. U.S.A. 106, 4677-4682. doi: 10.1073/pnas.0900666106

Liu, T., Chen, X., Ma, Z., Shokes, J., Hemmingsen, L., Scott, R. A., et al. (2008). A $\mathrm{Cu}(\mathrm{I})$-sensing ArsR family metal sensor protein with a relaxed metal selectivity profile. Biochemistry 47, 10564-10575. doi: 10.1021/bi801313y

Liu, T., Nakashima, S., Hirose, K., Shibasaka, M., Katsuhara, M., Ezaki, B., et al. (2004). A novel cyanobacterial SmtB/ArsR family repressor regulates the expression of a CPx-ATPase and a metallothionein in response to both $\mathrm{Cu}(\mathrm{I}) / \mathrm{Ag}(\mathrm{I})$ and $\mathrm{Zn}(\mathrm{II}) / \mathrm{Cd}(\mathrm{II})$. J. Biol. Chem. 279, 17810-17818. doi: 10.1074/jbc.M310560200

Liu, T., Ramesh, A., Ma, Z., Ward, S. K., Zhang, L. M., George, G. N., et al. (2007). CsoR is a novel Mycobacterium tuberculosis copper-sensing transcriptional regulator. Nat. Chem. Biol. 3, 60-68. doi: 10.1038/nchembio844

Lohmeyer, E., Schroder, S., Pawlik, G., Trasnea, P. I., Peters, A., Daldal, F., et al. (2012). The ScoI homologue SenC is a copper binding protein that interacts directly with the cbb(3)-type cytochrome oxidase in Rhodobacter capsulatus. Biochim. Biophys. Acta 1817, 2005-2015. doi: 10.1016/j.bbabio.2012.06.621

Lutkenhaus, J. F. (1977). Role of a major outer membrane protein in Escherichia coli. J. Bacteriol. 131, 631-637.

Ma, Z., Cowart, D. M., Scott, R. A., and Giedroc, D. P. (2009a). Molecular insights into the metal selectivity of the Copper(I)-sensing repressor CsoR from Bacillus subtilis. Biochemistry 48, 3325-3334. doi: 10.1021/bi900115w

Ma, Z., Cowart, D. M., Ward, B. P., Arnold, R. J., DiMarchi, R. D., Zhang, L. M., et al. (2009b). Unnatural amino acid substitution as a probe of the allosteric coupling pathway in a mycobacterial $\mathrm{Cu}(\mathrm{I})$ sensor. J. Am. Chem. Soc. 131, 18044-18045. doi: 10.1021/ja908372b

Ma, Z., Jacobsen, F. E., and Giedroc, D. P. (2009c). Coordination chemistry of bacterial metal transport and sensing. Chem. Rev. 109, 4644-4681. doi: $10.1021 / \mathrm{cr} 900077 \mathrm{w}$

Macomber, L., and Imlay, J. A. (2009). The iron-sulfur clusters of dehydratases are primary intracellular targets of copper toxicity. Proc. Natl. Acad. Sci. U.S.A. 106, 8344-8349. doi: 10.1073/pnas.0812808106

Mandal, A. K., and Argüello, J. M. (2003). Functional roles of metal binding domains of the Archaeoglobus fulgidus $\mathrm{Cu}^{+}$-ATPase CopA. Biochemistry 42, 11040-11047. doi: 10.1021/bi034806y

Matoba, Y., Kumagai, T., Yamamoto, A., Yoshitsu, H., and Sugiyama, M. (2006). Crystallographic evidence that the dinuclear copper center of tyrosinase is flexible during catalysis. J. Biol. Chem. 281, 8981-8990. doi: 10.1074/jbc.M509785200

Mealman, T. D., Bagai, I., Singh, P., Goodlett, D. R., Rensing, C., Zhou, H., et al. (2011). Interactions between CusF and CusB identified by NMR spectroscopy and chemical cross-linking coupled to mass spectrometry. Biochemistry 50, 2559-2566. doi: 10.1021/bi102012j

Mellano, M. A., and Cooksey, D. A. (1988a). Induction of the copper resistance operon from Pseudomonas syringae. J. Bacteriol. 170, 4399-4401.

Mellano, M. A., and Cooksey, D. A. (1988b). Nucleotide sequence and organization of copper resistance genes from Pseudomonas syringae pv. tomato. J. Bacteriol. 170, 2879-2883.

Messerschmidt, A., Luecke, H., and Huber, R. (1993). X-ray structures and mechanistic implications of three functional derivatives of ascorbate oxidase from zucchini. Reduced, peroxide and azide forms. J. Mol. Biol. 230, 997-1014. doi: 10.1006/jmbi.1993.1215

Munson, G. P., Lam, D. L., Outten, F. W., and O'Halloran, T. V. (2000). Identification of a copper-responsive two-component system on the chromosome of Escherichia coli K-12. J. Bacteriol. 182, 5864-5871. doi: 10.1128/JB.182.20.5864-5871.2000

Nakamura, K., and Go, N. (2005). Function and molecular evolution of multicopper blue proteins. Cell. Mol. Life Sci. 62, 2050-2066. doi: 10.1007/s00018-0045076-x

Nakamura, K., Kawabata, T., Yura, K., and Go, N. (2003). Novel types of twodomain multi-copper oxidases: possible missing links in the evolution. FEBS Lett. 553, 239-244. doi: 10.1016/S0014-5793(03)01000-7

Nguyen, H. H., Elliott, S. J., Yip, J. H., and Chan, S. I. (1998). The particulate methane monooxygenase from Methylococcus capsulatus (Bath) is a novel 
copper-containing three-subunit enzyme. Isolation and characterization. J. Biol. Chem. 273, 7957-7966. doi: 10.1074/jbc.273.14.7957

Nguyen, H.-H. T., Nakagawa, K. H., Hedman, B., Elliott, S. J., Lidstrom, M. E., Hodgson, K. O., et al. (1996). X-ray absortion and EPR studies on the copper ions associated with the particulate methane monooxygenase from Methylococcus capsulatus (Bath). $\mathrm{Cu}(\mathrm{I})$ ions and their implications. J. Am. Chem. Soc. 118, 12766-12776. doi: 10.1021/ja961778g

Nielsen, A. K., Gerdes, K., and Murrell, J. C. (1997). Copper-dependent reciprocal transcriptional regulation of methane monooxygenase genes in Methylococcus capsulatus and Methylosinus trichosporium. Mol. Microbiol. 25, 399-409. doi: 10.1046/j.1365-2958.1997.4801846.x

Odermatt, A., Suter, H., Krapf, R., and Solioz, M. (1993). Primary structure of two P-type ATPases involved in copper homeostasis in Enterococcus hirae. J. Biol. Chem. 268, 12775-12779.

Osman, D., and Cavet, J. S. (2008). Copper homeostasis in bacteria. Adv. Appl. Microbiol. 65, 217-247. doi: 10.1016/S0065-2164(08)00608-4

Osman, D., Patterson, C. J., Bailey, K., Fisher, K., Robinson, N. J., Rigby, S. E., et al. (2013). The copper supply pathway to a Salmonella $\mathrm{Cu}, \mathrm{Zn}$-superoxide dismutase (SodCII) involves $\mathrm{P}_{1 \mathrm{~B}}$-type ATPase copper efflux and periplasmic CueP. Mol. Microbiol. 87, 466-477. doi: 10.1111/mmi.12107

Osman, D., Waldron, K. J., Denton, H., Taylor, C. M., Grant, A. J., Mastroeni, P., et al. (2010). Copper homeostasis in Salmonella is atypical and copper-CueP is a major periplasmic metal complex. J. Biol. Chem. 285, 25259-25268. doi: 10.1074/jbc.M110.145953

Outten, F. W., Huffman, D. L., Hale, J. A., and O'Halloran, T. V. (2001). The independent cue and cus systems confer copper tolerance during aerobic and anaerobic growth in Escherichia coli. J. Biol. Chem. 276, 30670-30677. doi: 10.1074/jbc.M104122200

Outten, F. W., Outten, C. E., Hale, J., and O'Halloran, T. V. (2000). Transcriptional activation of an Escherichia coli copper efflux regulon by the chromosomal MerR homologue, cueR. J. Biol. Chem. 275, 31024-31029. doi: 10.1074/jbc.M006508200

Padilla-Benavides, T., Long, J. E., Raimunda, D., Sassetti, C. M., and Argüello, J. M. (2013a). A novel $\mathrm{P}_{1 \mathrm{~B}}$-type $\mathrm{Mn}^{2+}$-transporting ATPase is required for secreted protein metallation in mycobacteria. J. Biol. Chem. 288, 11334-11347. doi: 10.1074/jbc.M112.448175

Padilla-Benavides, T., McCann, C. J., and Argüello, J. M. (2013b). The mechanism of $\mathrm{Cu}^{+}$transport ATPases: Interaction with $\mathrm{Cu}^{+}$chaperones and the role of transient metal-binding sites. J. Biol. Chem. 288, 69-78. doi: 10.1074/jbc.M112.420810

Palmgren, M. G., and Nissen, P. (2011). P-type ATPases. Annu. Rev. Biophys. 40, 243-266. doi: 10.1146/annurev.biophys.093008.131331

Pang, W. L., Kaur, A., Ratushny, A. V., Cvetkovic, A., Kumar, S., Pan, M., et al. (2013). Metallochaperones regulate intracellular copper levels. PLoS Comput. Biol. 9:e1002880. doi: 10.1371/journal.pcbi.1002880

Pontel, L. B., and Soncini, F. C. (2009). Alternative periplasmic copper-resistance mechanisms in Gram negative bacteria. Mol. Microbiol. 73, 212-225. doi: 10.1111/j.1365-2958.2009.06763.x

Puig, S., Lee, J., Lau, M., and Thiele, D. J. (2002). Biochemical and genetic analyses of yeast and human high affinity copper transporters suggest a conserved mechanism for copper uptake. J. Biol. Chem. 277, 26021-26030. doi: 10.1074/jbc.M202547200

Raimunda, D., González-Guerrero, M., Leeber, B. W. 3rd., and Argüello, J. M. (2011). The transport mechanism of bacterial $\mathrm{Cu}^{+}$-ATPases: distinct efflux rates adapted to different function. Biometals 24, 467-475. doi: 10.1007/s10534-0109404-3

Raimunda, D., Padilla-Benavides, T., Vogt, S., Boutigny, S., Tomkinson, K. N., Finney, L. A., et al. (2013). Periplasmic response upon disruption of transmembrane $\mathrm{Cu}^{+}$transport in Pseudomonas aeruginosa. Metallomics 5, 144-151. doi: $10.1039 / \mathrm{c} 2 \mathrm{mt} 20191 \mathrm{~g}$

Rapisarda, V. A., Chehin, R. N., De Las Rivas, J., Rodriguez-Montelongo, L., Farías, R. N., and Massa, E. M. (2002). Evidence for Cu(I)-thiolate ligation and prediction of a putative copper-binding site in the Escherichia coli NADH dehydrogenase-2. Arch. Biochem. Biophys. 405, 87-94. doi: 10.1016/S00039861(02)00277-1

Rapisarda, V. A., Montelongo, L. R., Farías, R. N., and Massa, E. M. (1999). Characterization of an NADH-linked cupric reductase activity from the Escherichia coli respiratory chain. Arch. Biochem. Biophys. 370, 143-150. doi: 10.1006/abbi.1999.1398
Reddy, V. S., Shlykov, M. A., Castillo, R., Sun, E. I., and Saier, M. H. Jr. (2012). The major facilitator superfamily (MFS) revisited. FEBS J. 279, 2022-2035. doi: 10.1111/j.1742-4658.2012.08588.x

Redinbo, M. R., Yeates, T. O., and Merchant, S. (1994). Plastocyanin: structural and functional analysis. J. Bioenerg. Biomembr. 26, 49-66. doi: 10.1007/BF00763219

Rensing, C., Fan, B., Sharma, R., Mitra, B., and Rosen, B. P. (2000). CopA: An Escherichia coli $\mathrm{Cu}(\mathrm{I})$-translocating P-type ATPase. Proc. Natl. Acad. Sci. U.S.A. 97, 652-656. doi: 10.1073/pnas.97.2.652

Rensing, C., and Grass, G. (2003). Escherichia coli mechanisms of copper homeostasis in a changing environment. FEMS Microbiol. Rev. 27, 197-213. doi: 10.1016/S0168-6445(03)00049-4

Rensing, C., and McDevitt, S. F. (2013). The copper metallome in prokaryotic cells. Met. Ions Life Sci. 12, 417-450. doi: 10.1007/978-94-007-5561-1_12

Reyes-Caballero, H., Campanello, G. C., and Giedroc, D. P. (2011). Metalloregulatory proteins: metal selectivity and allosteric switching. Biophys. Chem. 156, 103-114. doi: 10.1016/j.bpc.2011.03.010

Richter, O. M. H., and Ludwig, B. (2003). Cytochrome $c$ oxidase-structure, function, and physiology of a redox-driven molecular machine. Rev. Physiol. Biochem. Pharmacol. 147, 47-74. doi: 10.1007/s10254-003-0006-0

Ridge, P. G., Zhang, Y., and Gladyshev, V. N. (2008). Comparative genomic analyses of copper transporters and cuproproteomes reveal evolutionary dynamics of copper utilization and its link to oxygen. PLoS ONE 3:e1378. doi: 10.1371/journal.pone. 0001378

Roberts, S. A., Weichsel, A., Grass, G., Thakali, K., Hazzard, J. T., Tollin, G., et al. (2002). Crystal structure and electron transfer kinetics of CueO, a multicopper oxidase required for copper homeostasis in Escherichia coli. Proc. Natl. Acad. Sci. U.S.A. 99, 2766-2771. doi: 10.1073/pnas.052710499

Robinson, N. J., and Winge, D. R. (2010). Copper metallochaperones. Annu. Rev. Biochem. 79, 537-562. doi: 10.1146/annurev-biochem-030409-143539

Rodríguez-Montelongo, L., Farías, R. N., and Massa, E. M. (1995). Sites of electron transfer to membrane-bound copper and hydroperoxide-induced damage in the respiratory chain of Escherichia coli. Arch. Biochem. Biophys. 323, 19-26. doi: 10.1006/abbi.1995.0004

Rodríguez-Montelongo, L., Volentini, S. I., Farías, R. N., Massa, E. M., and Rapisarda, V. A. (2006). The Cu(II)-reductase NADH dehydrogenase-2 of Escherichia coli improves the bacterial growth in extreme copper concentrations and increases the resistance to the damage caused by copper and hydroperoxide. Arch. Biochem. Biophys. 451, 1-7. doi: 10.1016/j.abb.2006.04.019

Rouch, D. A., and Brown, N. L. (1997). Copper-inducible transcriptional regulation at two promoters in the Escherichia coli copper resistance determinant pco. Microbiology 143(Pt 4), 1191-1202. doi: 10.1099/00221287-143-4-1191

Rowland, J. L., and Niederweis, M. (2012). Resistance mechanisms of Mycobacterium tuberculosis against phagosomal copper overload. Tuberculosis (Edinb) 92, 202-210. doi: 10.1016/j.tube.2011.12.006

Rushing, M. D., and Slauch, J. M. (2011). Either periplasmic tethering or protease resistance is sufficient to allow a SodC to protect Salmonella enterica serovar Typhimurium from phagocytic superoxide. Mol. Microbiol. 82, 952-963. doi: 10.1111/j.1365-2958.2011.07884.x

Sakamoto, K., Agari, Y., Agari, K., Kuramitsu, S., and Shinkai, A. (2010). Structural and functional characterization of the transcriptional repressor CsoR from Thermus thermophilus HB8. Microbiology 156, 1993-2005. doi: 10.1099/mic.0.037382-0

Saunders, N. F., Hornberg, J. J., Reijnders, W. N., Westerhoff, H. V., de Vries, S., and van Spanning, R. J. (2000). The NosX and NirX proteins of Paracoccus denitrificans are functional homologues: their role in maturation of nitrous oxide reductase. J. Bacteriol. 182, 5211-5217. doi: 10.1128/JB.182.18.5211-5217.2000

Semrau, J. D., Chistoserdov, A., Lebron, J., Costello, A., Davagnino, J., Kenna, E., et al. (1995). Particulate methane monooxygenase genes in methanotrophs. J. Bacteriol. 177, 3071-3079.

Serventi, F., Youard, Z. A., Murset, V., Huwiler, S., Buhler, D., Richter, M., et al. (2012). Copper starvation-inducible protein for cytochrome oxidase biogenesis in Bradyrhizobium japonicum. J. Biol. Chem. 287, 38812-38823. doi: 10.1074/jbc.M112.406173

Silva, J. J. R. F. D., and Williams, R. J. P. (2001). The Biological Chemistry of the Elements: The Inorganic Chemistry of Life. 2nd Edn. Oxford, NY: Oxford University Press.

Singh, S. K., Grass, G., Rensing, C., and Montfort, W. R. (2004). Cuprous oxidase activity of CueO from Escherichia coli. J. Bacteriol. 186, 7815-7817. doi: 10.1128/JB.186.22.7815-7817.2004 
Siroy, A., Mailaender, C., Harder, D., Koerber, S., Wolschendorf, F., Danilchanka, O., et al. (2008). Rv1698 of Mycobacterium tuberculosis represents a new class of channel-forming outer membrane proteins. J. Biol. Chem. 283, 17827-17837. doi: 10.1074/jbc.M800866200

Smaldone, G. T., and Helmann, J. D. (2007). CsoR regulates the copper efflux operon copZA in Bacillus subtilis. Microbiology 153, 4123-4128. doi: 10.1099/mic.0.2007/011742-0

Solioz, M., Abicht, H. K., Mermod, M., and Mancini, S. (2010). Response of Gram-positive bacteria to copper stress. J. Biol. Inorg. Chem. 15, 3-14. doi: 10.1007/s00775-009-0588-3

Stolyar, S., Costello, A. M., Peeples, T. L., and Lidstrom, M. E. (1999). Role of multiple gene copies in particulate methane monooxygenase activity in the methane-oxidizing bacterium Methylococcus capsulatus (Bath). Microbiology 145(Pt 5), 1235-1244. doi: 10.1099/13500872-145-5-1235

Su, C. C., Yang, F., Long, F., Reyon, D., Routh, M. D., Kuo, D. W., et al. (2009). Crystal structure of the membrane fusion protein CusB from Escherichia coli. J. Mol. Biol. 393, 342-355. doi: 10.1016/j.jmb.2009.08.029

Swem, D. L., Swem, L. R., Setterdahl, A., and Bauer, C. E. (2005). Involvement of SenC in assembly of cytochrome $c$ oxidase in Rhodobacter capsulatus. J. Bacteriol. 187, 8081-8087. doi: 10.1128/JB.187.23.8081-8087.2005

Tavares, P., Pereira, A. S., Moura, J. J., and Moura, I. (2006). Metalloenzymes of the denitrification pathway. J. Inorg. Biochem. 100, 2087-2100. doi: 10.1016/j.jinorgbio.2006.09.003

Teitzel, G. M., Geddie, A., De Long, S. K., Kirisits, M. J., Whiteley, M., and Parsek, M. R. (2006). Survival and growth in the presence of elevated copper: transcriptional profiling of copper-stressed Pseudomonas aeruginosa. J. Bacteriol. 188, 7242-7256. doi: 10.1128/JB.00837-06

Tetaz, T. J., and Luke, R. K. (1983). Plasmid-controlled resistance to copper in Escherichia coli. J. Bacteriol. 154, 1263-1268.

Tottey, S., Patterson, C. J., Banci, L., Bertini, I., Felli, I. C., Pavelkova, A., et al. (2012). Cyanobacterial metallochaperone inhibits deleterious side reactions of copper. Proc. Natl. Acad. Sci. U.S.A. 109, 95-100. doi: 10.1073/pnas. 1117515109

Tottey, S., Rich, P. R., Rondet, S. A., and Robinson, N. J. (2001). Two Menkes-type ATPases supply copper for photosynthesis in Synechocystis PCC (6803). J. Biol. Chem. 276, 19999-20004. doi: 10.1074/jbc.M011243200

Wilmot, C. M., Murray, J. M., Alton, G., Parsons, M. R., Convery, M. A., Blakeley, V., et al. (1997). Catalytic mechanism of the quinoenzyme amine oxidase from Escherichia coli: exploring the reductive half-reaction. Biochemistry 36, 1608-1620. doi: 10.1021/bi962205j

Wolschendorf, F., Ackart, D., Shrestha, T. B., Hascall-Dove, L., Nolan, S., Lamichhane, G., et al. (2011). Copper resistance is essential for virulence of
Mycobacterium tuberculosis. Proc. Natl. Acad. Sci. U.S.A. 108, 1621-1626. doi: 10.1073/pnas. 1009261108

Wunsch, P., Herb, M., Wieland, H., Schiek, U. M., and Zumft, W. G. (2003). Requirements for $\mathrm{Cu}(\mathrm{A})$ and $\mathrm{Cu}-\mathrm{S}$ center assembly of nitrous oxide reductase deduced from complete periplasmic enzyme maturation in the nondenitrifier Pseudomonas putida. J. Bacteriol. 185, 887-896. doi: 10.1128/JB.185.3.887896.2003

Xue, Y., Davis, A. V., Balakrishnan, G., Stasser, J. P., Staehlin, B. M., Focia, P., et al. (2008). Cu(I) recognition via cation-pi and methionine interactions in CusF. Nat. Chem. Biol. 4, 107-109. doi: 10.1038/nchembio.2007.57

Yamamoto, K., and Ishihama, A. (2005). Transcriptional response of Escherichia coli to external copper. Mol. Microbiol. 56, 215-227. doi: 10.1111/j.13652958.2005.04532.x

Zaballa, M. E., Abriata, L. A., Donaire, A., and Vila, A. J. (2012). Flexibility of the metal-binding region in apo-cupredoxins. Proc. Natl. Acad. Sci. U.S.A. 109, 9254-9259. doi: 10.1073/pnas.1119460109

Zahn, J. A., and DiSpirito, A. A. (1996). Membrane-associated methane monooxygenase from Methylococcus capsulatus (Bath). J. Bacteriol. 178, 1018-1029.

Zgurskaya, H. I., and Nikaido, H. (1999). AcrA is a highly asymmetric protein capable of spanning the periplasm. J. Mol. Biol. 285, 409-420. doi: 10.1006/jmbi.1998.2313

Zumft, W. G. (2005). Nitric oxide reductases of prokaryotes with emphasis on the respiratory, heme-copper oxidase type. J. Inorg. Biochem. 99, 194-215. doi: 10.1016/j.jinorgbio.2004.09.024

Conflict of Interest Statement: The authors declare that the research was conducted in the absence of any commercial or financial relationships that could be construed as a potential conflict of interest.

Received: 24 August 2013; accepted: 17 October 2013; published online: 05 November 2013.

Citation: Argüello JM, Raimunda D and Padilla-Benavides T (2013) Mechanisms of copper homeostasis in bacteria. Front. Cell. Infect. Microbiol. 3:73. doi: 10.3389/fcimb. 2013.00073

This article was submitted to the journal Frontiers in Cellular and Infection Microbiology.

Copyright (c) 2013 Argüello, Raimunda and Padilla-Benavides. This is an openaccess article distributed under the terms of the Creative Commons Attribution License (CC BY). The use, distribution or reproduction in other forums is permitted, provided the original author(s) or licensor are credited and that the original publication in this journal is cited, in accordance with accepted academic practice. No use, distribution or reproduction is permitted which does not comply with these terms. 